\title{
Performance of experimental bioretention cells during the first year of operation
}

\author{
Petra Hečková ${ }^{1,2 *}$, Vojtěch Bareš ${ }^{1}$, David Stránský ${ }^{1}$, Michal Sněhota ${ }^{1,2}$ \\ ${ }^{1}$ Czech Technical University in Prague, Faculty of Civil Engineering, Thákurova 7, Prague 6, 166 29, Czech Republic. \\ ${ }^{2}$ Czech Technical University in Prague, University Centre for Energy Efficient Buildings, Třinecká 1024, Buštěhrad, 273 43, Czech \\ Republic. \\ * Corresponding author. E-mail: petra.heckova@cvut.cz
}

\begin{abstract}
Detailed data on the long-term performance of bioretention cells (BC) for stormwater management are sparse. This research aimed at setting up and testing an infrastructure that will provide the data on hydrologic and chemical performance of BC. Two identical experimental BC's were built. The monitoring methodology monitoring was developed and tested during a first growing season with the first BC supplied with natural rainfall, while the second BC was used for ponding experiments. Key layer of the BCs, a biofilter, was composed of sand, compost and topsoil. Both $\mathrm{BCs}$ are equipped with sensors monitoring the components of water balance and the water potential of the biofilter. High levels of total suspended solids were detected in the outflow. The runoff coefficient for the entire period of the growing season was 0.72 in the first $\mathrm{BC}$ and 0.86 in the second $\mathrm{BC}$, while the peak outflow reduction for individual rainfall episodes ranged between $75 \%$ to $95 \%$ for the first $\mathrm{BC}$ and $19 \%$ to $30 \%$ for the second BC. Saturated hydraulic conductivity of the biofilter in the first BC decreased by two orders of magnitudes after the first year of operation. Retention curves of the biofilter changed due to material consolidation.
\end{abstract}

Keywords: Bioretention; Biofilter; Water retention; Constructed soil; Stormwater; Infiltration.

\section{INTRODUCTION}

Ever-increasing urbanization contributes to an increase in the coverage of impervious surfaces which leads to increased runoff and more frequent flash floods, decreased groundwater recharge and the formation of the heat island effect (Booth et al., 2002; Hollis, 1977; Marsalek et al., 1993; Qin et al., 2013). In the past few decades, Nature-based solutions (NBS) for stormwater management has been increasingly implemented to reduce peak runoff and volume, enhance infiltration and evapotranspiration, as well as reduce storm water pollution towards pre-development levels (Kabisch et al., 2017). NBS approaches for stormwater management are also known under the terms Low Impact Development (LID), Water Sensitive Urban Design (WSUD), SuSD (Sustainable Drainage Systems) or Best practice management (BPM) according to regional/continental terminology and some nuances (Fletcher et al., 2015). Infiltration swales, green roofs, and permeable pavements are frequent examples of the NBS that generally aim at the replication of natural hydrological processes in urbanized areas (Coffman and France, 2002; Dietrich et al., 2017). One of the measures particularly applicable to stormwater infiltration at a wide range of scales are bioretention cells (Hatt et al., 2009; Liao et al., 2017). Bioretention cells (BC), also known as rain gardens (or biofilters), are soil-plant based artificial surface depressions covered with a mulch layer on top of which could be planted shrubs, perennials, or trees. In the following text, the term bioretention cell is used. Bioretention cells promote accumulation, infiltration, treatment and evapotranspiration. In the study of Dietz and Clausen (2005) bioretention cells of the rain garden type proved to be an effective device for reducing stormwater flow (Recanatesi et al., 2017; Villarreal et al., 2004). Several studies reported a reduction in peak runoff of more than $90 \%$ (Bortolini and Zanin, 2018, 2017; Brown and Hunt, 2012; DeBusk and
Wynn, 2011; Hunt et al., 2008; Shrestha, 2018). The function of the $\mathrm{BC}$ relies on the performance of the biofilter soil layer which is formed, in many cases, by specifically designed constructed soil (Gulbaz and Kazezyilmaz-Alhan, 2017; Hatt et al., 2009) mostly composed of sand, various types of topsoil and organic material. The ratio of these components affects the resulting retention properties (Willaredt and Nehls, 2021) hydraulic conductivity of the mixture, which predetermines the infiltration rate in the bioretention cell and the overall functioning of the biofilter layer (Zhang and Chui, 2017). Gulbaz and Kazezyilmaz-Alhan (2017) showed that a high sand ratio decreases the arrival time of a peak flow bioretention system and increases the outflow peak whereas high clay and silt contents increase the arrival time and decrease the peak of the outflow of the bioretention system. The composition of the soil used as biofilter reported in the literature varies quite widely. Paus et al. (2016) recommended that the hydraulic conductivity of the bioretention soil layer is higher than $10 \mathrm{~cm} \cdot \mathrm{h}^{-1}$ for a successfully operating BC. The Melbourne water manual recommends initial hydraulic conductivity between 5 and $20 \mathrm{~cm} \cdot \mathrm{h}^{-1}$ (Melbourne water, 2005). Table 1 lists examples of biofilter composition reported in the literature.

The function of the biofilter depends not only on its initial physical and chemical properties, but also on a subsequent soil pedogenesis (Jangorzo et al., 2013; Scalenghe and Ferraris, 2009; Sere et al., 2012) that occurs after installation and determines the development of the soil structure, changes in organic matter content, the formation of macropores, soil stratification, clogging of pores by particles, and alterations of soil wettability. The long-term functioning of BCs is not yet entirely understood because long-term experimental studies on this topic are still sparse and results are not always consistent (Dietz, 2007). The results of some studies showed no signs of a systematic decline in performance after six years (Jenkins et al., 2010) and 
Table 1. Composition of bioretention soil used in different studies. Physical and chemical properties of bioretention soil.

\begin{tabular}{|c|c|c|c|c|c|}
\hline Biofilter composition & $\begin{array}{l}\text { Chemical and physical } \\
\text { properties of biofilter }\end{array}$ & $\begin{array}{l}\text { Thickness of } \\
\text { biofilter }(\mathrm{cm})\end{array}$ & $\begin{array}{l}\text { Runoff volume } \\
\text { reduction }\end{array}$ & $\begin{array}{l}\text { Peak flow } \\
\text { reduction }\end{array}$ & Source \\
\hline $\begin{array}{l}88 \% \text { sand, } 8 \% \text { fines }(\text { clay }+ \text { silt }), \\
4 \% \text { organic material }\end{array}$ & $* *$ & 180 & $97 \%$ & $99 \%$ & $\begin{array}{l}\text { (DeBusk and Wynn, } \\
\text { 2011) }\end{array}$ \\
\hline $\begin{array}{l}50 \% \text { sand, } 30 \% \\
\text { topsoil, } 20 \% \text { OM }\end{array}$ & ** & $\begin{array}{c}90 \\
120\end{array}$ & $\begin{array}{l}52 \% \\
64 \%\end{array}$ & $\begin{array}{l}44 \% \\
63 \%\end{array}$ & (Davis, 2008) \\
\hline $\begin{array}{l}50 \% \text { sand, } 25 \% \text { compost, } 25 \% \\
\text { topsoil }\end{array}$ & $* *$ & $* *$ & $* *$ & $* *$ & $\begin{array}{l}\text { (Bortolini and Zanin, } \\
\text { 2017) }\end{array}$ \\
\hline $87 \%$ sand, $13 \%$ fines & $* *$ & $\begin{array}{l}60 \\
90\end{array}$ & $\begin{array}{l}63-88 \% \\
65-89 \%\end{array}$ & $\begin{array}{l}84-92 \% \\
92-95 \%\end{array}$ & (Brown and Hunt, 2012) \\
\hline $\begin{array}{l}54 \% \text { sand, } 26 \% \text { silt, } 20 \% \text { clay, } \\
12,2 \% \text { organic matter }\end{array}$ & $* *$ & $* *$ & $* *$ & $* *$ & (Austin, 2012) \\
\hline $60 \%$ sand, $40 \%$ compost & pH: $6.27-7.36$ & 61 & $75 \%$ & $91 \%$ & (Shrestha, 2018) \\
\hline $63 \%$ sand, $23 \%$ silt, $14 \%$ clay & $* *$ & $* *$ & $* *$ & $* *$ & (Houdeshel et al., 2015) \\
\hline $54 \%$ sand, $46 \%$ fines & $* *$ & $50-80$ & $79 \%$ & $83 \%$ & $\begin{array}{l}\text { (Olszewski and Davis, } \\
\text { 2012) }\end{array}$ \\
\hline $\begin{array}{l}84.4 \% \text { sand, } 7.6 \% \text { silt, } 8.0 \% \\
\text { clay }\end{array}$ & $\begin{array}{l}\text { Bulk density: } 1.63 \mathrm{~g} \cdot \mathrm{cm}^{-3} \\
\text { Infiltration capacity: } 12.6 \\
\mathrm{~cm} \cdot \mathrm{h}^{-1} \\
\mathrm{pH}: 6.1 \\
\text { Organic matter: } 16.8 \% \\
\text { LOI* }\end{array}$ & ** & $* *$ & $* *$ & (Dietz and Clausen, 2005) \\
\hline $50 \%$ sand, $50 \%$ organic material & $* *$ & 50 & $* *$ & $* *$ & $\begin{array}{c}\text { (Aravena and Dussaillant- } \\
\text { Jones, 2009) }\end{array}$ \\
\hline
\end{tabular}

Note: *LOI: Loss-On-Ignition Method, ** Not provided

after two years (Emerson and Traver, 2008). Le Coustumer et al. (2009), on the other hand, reports that the hydraulic conductivity of biofilters has been reduced by more than half the initial value over a seven-year period. A study by Paus et al. (2016) states that air temperature affects the hydrological performance of a bioretention cell. The $K_{s}$ value decreases as temperature decreases. Other studies (Archer et al., 2002; Hatt et al., 2009, Muerdter et al., 2018) show that vegetation prevents the clogging of the bioretention medium which can be a solution for long-term functioning. Peak discharge reduction capabilities one of one recent system was compared to six years old system (Imteaz et al., 2015). Average peak flow reduction in the new system was $86 \%$ whereas average flow reduction through the old system was $89 \%$. Li et al. (2018) used the model based on solving Richards' equation (HYDRUS 1D) to simulate water flow in a bioretention cell. It was found that runoff reduction was more effective at lower rainfall intensities than at higher intensities. Numerical models have become an efficient mean of BC assessment. SWMM model (Huber, 1995) and MUSIC model (Wong et al., 2006) among others have been used to simulate the outflow from BCs. In a study by Aravena and Dussaillant-Jones (2009), a model created in the Hydrus 2D (Šimůnek et al., 2008) proved to be a suitable for modeling of effluent from a bioretention cell.

The literature research shows that there has been a need for long-term experiments on bioretention cells. Such research would, in the end, enable the assessment of the time development of biofilter properties, their overall performance and provide reliable data for model validation.
The aim of this study was to set-up and evaluate the performance of pilot experimental bioretention cells and to develop and test the methodology of monitoring and infiltration experiments for an upcoming long-term monitoring study. The focus was on the evaluation of the rainfall-runoff characteristics, the assessment of early changes of the hydraulic properties of the biofilter layer, the description of growth of four perennial plant species and the characterization of selected chemical properties of effluent water.

\section{MATERIALS AND METHODS Site characterization}

Two identical experimental bioretention cells were built on the premises of the University Centre for Energy Efficient Buildings (UCEEB), at the Czech Technical University in Prague (CTU), located in Buštěhrad, Czech Republic $\left(50^{\circ} 9.41797^{\prime} \mathrm{N}, 14^{\circ} 10.19195^{\prime} \mathrm{E}, 355 \mathrm{~m}\right.$ a.s.l.) in December 2017. The site shown in Fig. 1 is located in a region characterized as temperate, with an average annual rainfall between 500 and $550 \mathrm{~mm}$, and an average air temperature of $8{ }^{\circ} \mathrm{C}$. The meteorological station equipped with sensors of air temperature at 7 and $200 \mathrm{~cm}$ above ground, relative humidity, wind speed and direction and precipitation is located east of the bioretention cells in the distance of $10 \mathrm{~m}$. The weather observations were processed every $10 \mathrm{~s}$ and recorded as 1-min averages. Weather conditions during the period are presented in electronic supplementary material Figs. S1 and S2. The evaluating period was from June 6, 2018, when the monitoring system was initiated, to November 22, 2018, when the soil in the bioretention cells 


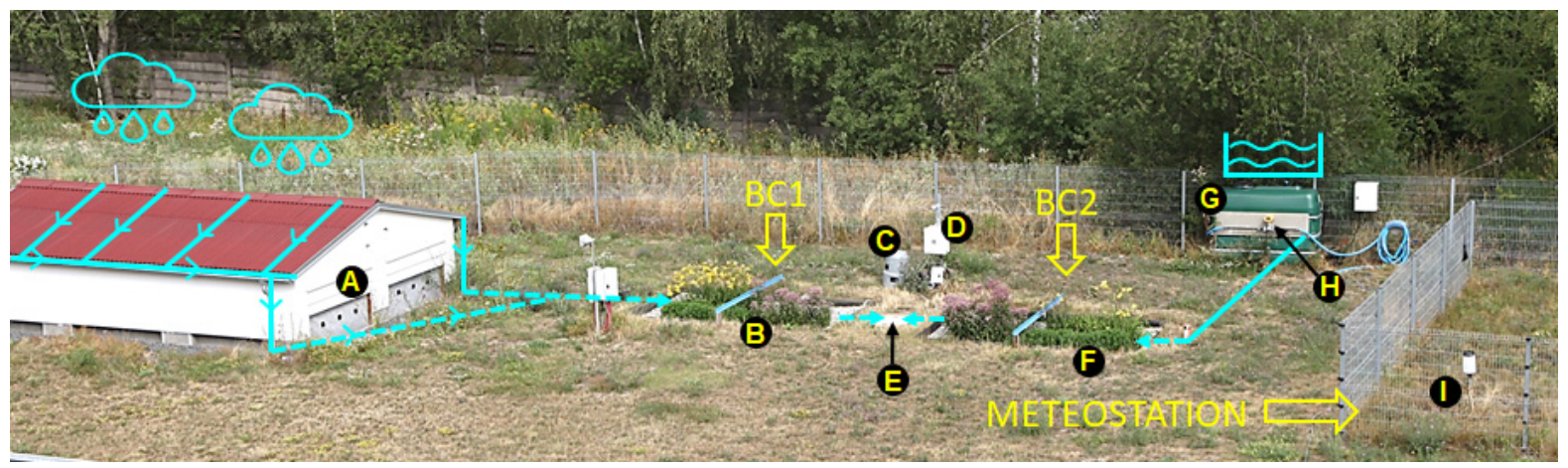

Fig. 1. Photography of the experimental site: a) drained roof; b) experimental bioretention cell 1 (BC1); c) automatic sampler; d) data logger; e) shaft with two tipping bucket flowmeters; f) experimental bioretention cell 2 (BC2); g) water tank with pump system; h) flowmeter; i) rain gauge.

a)

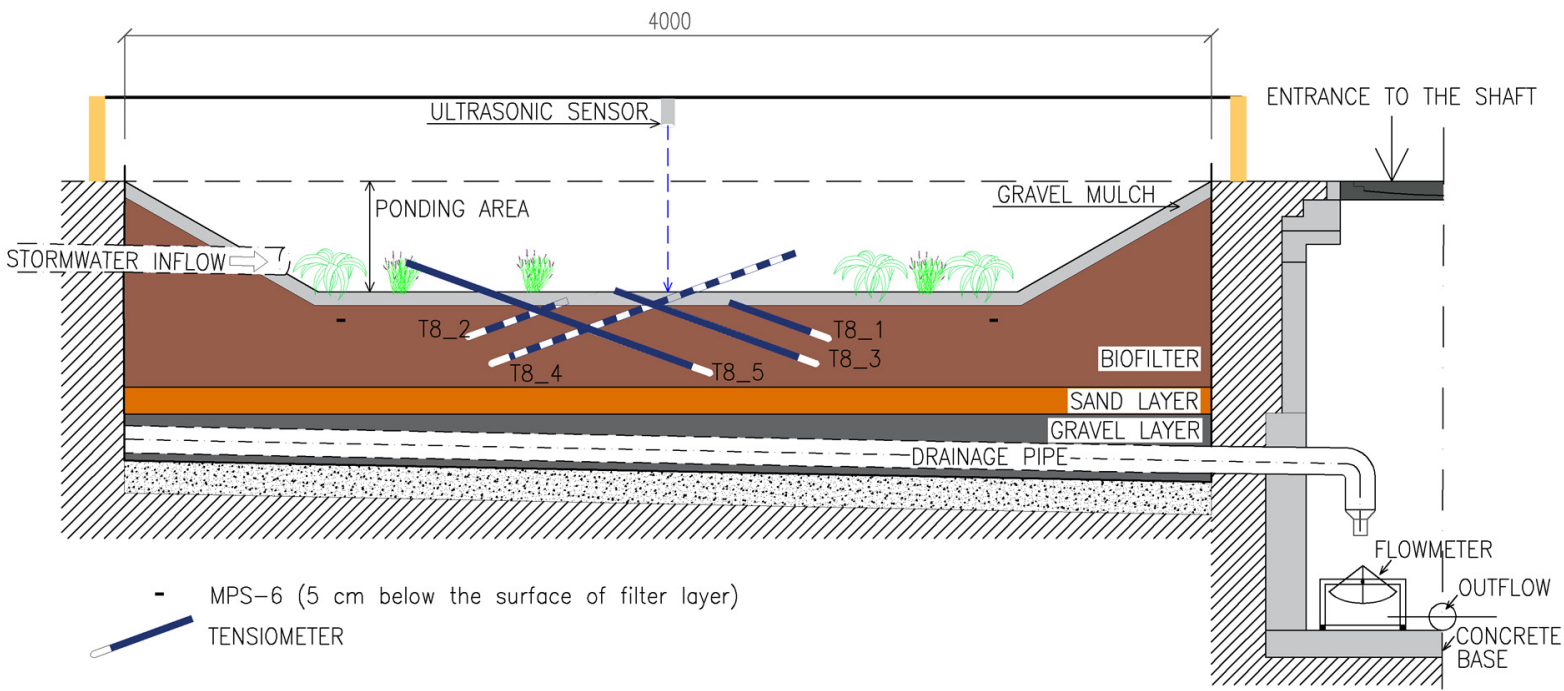

b)

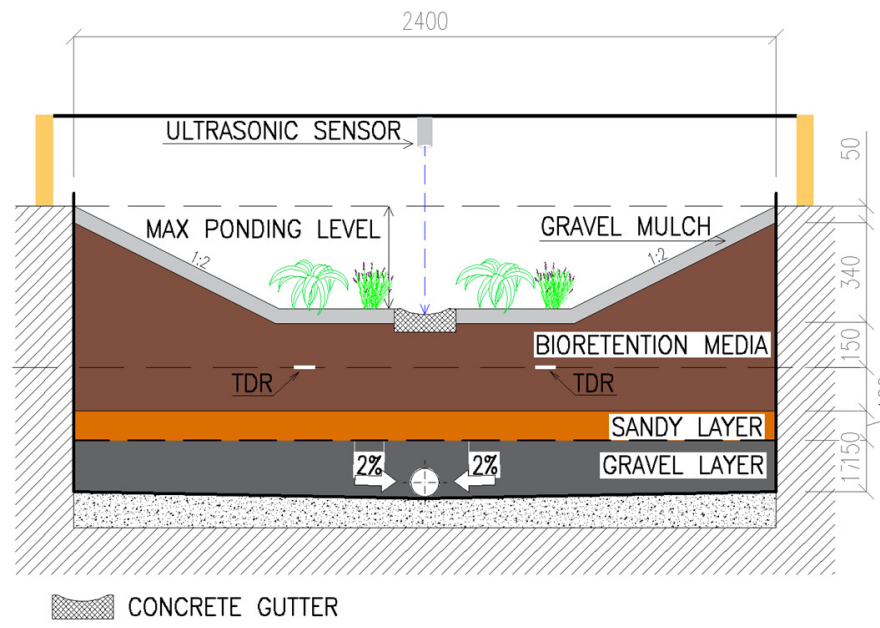

c)

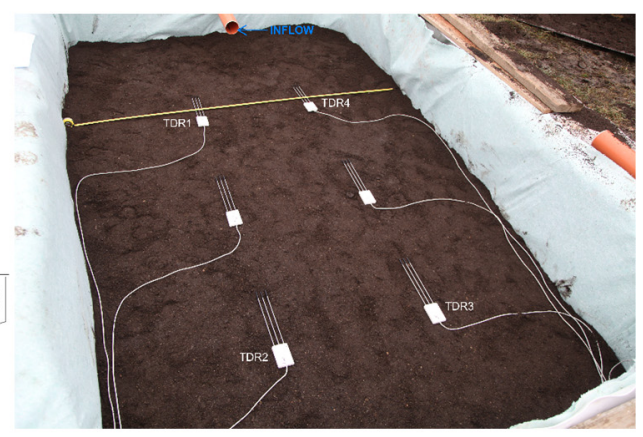

Fig. 2. Schema of one experimental bioretention cell shown as a) longitudinal cross sections and b) a transverse cross section. Photograph c) shows the location of TDR probes placed upon the filling of the bioretention cell. Note that only the outer four TDR probes were involved in the monitoring due to limited capacity of the TDR multiplexor

started to freeze. The maximum monthly total rainfall depth of $47.4 \mathrm{~mm}$ was recorded in August. The total rainfall depth was $138 \mathrm{~mm}$ during the evaluated period. The average air temperature at $200 \mathrm{~cm}$ above the grassland surface during the monitoring period was $16.0^{\circ} \mathrm{C}$, the maximum air temperature reached $37.4{ }^{\circ} \mathrm{C}$, and the minimum air temperature was $-5.0{ }^{\circ} \mathrm{C}$. Wind speed ranged between 0 and $4 \mathrm{~m} \cdot \mathrm{s}^{-1}$ and rising wind clearly showed the prevailing southwestern wind direction at the site of experiments. The 2018 growing period was significantly dryer than the long-term average in the region.

\section{Experimental bioretention cells: The set-up}

The first bioretention cell (BC1) collected stormwater from the roof of the nearby experimental building (roof area $38 \mathrm{~m}^{2}$, bitumen roof sheets, slope $14^{\circ}$ ) (Fig. 1). The second bioreten- 
tion cell (BC2) was created from a $2 \mathrm{~m}^{3}$ water storage tank using a controlled pump system. Fig. 2 depicts the schematic of one bioretention cell. The size and design of the drainage was designed according to the Czech national technical standard TVN 759011 (Kabelkova et al., 2013). The experimental setup was designed with unregulated drain to allow measurements of the actual outflow from the BC. Each bioretention cell was 2.4 $\mathrm{m}$ wide and $4.0 \mathrm{~m}$ long. The maximum depth of the ponding was $0.3 \mathrm{~m}$. The 5 -cm-thick mulching layer, made of grade $16 / 32 \mathrm{~mm}$ gravel, protected the surface from water erosion, weed growth, and evaporation. The 0.3 -m-thick bioretention soil layer was constructed as a mixture of sand, compost and topsoil in a 50:30:20\% mass ratio. The chemical properties of the soil extract are included in the supplementary material. The $0.27-\mathrm{m}$-thick drainage layer consisted of a gravel fraction of $16 / 32 \mathrm{~mm}$. The drainage layer and biofilter were separated by a 0.1 -m-thick sandy layer (fraction $0 / 4 \mathrm{~mm}$ ) designed for fine particle trapping. The sandy and drainage layer is separated by a geotextile $\left(200 \mathrm{~g} \cdot \mathrm{m}^{-2}\right)$. The body of the experimental bioretention cell was entirely isolated from the surrounding soil by the PVC membrane.

Four species of perennial plants (Aster novae-angliae 'Purple Dome'; Hemerocallis 'Lemon Bells'; Euphorbia amygdaloides; Molinia caerulea) were planted in each bioretention cell, in addition to five seedlings of Aster novae-angliae, Hemerocallis and Euphorbia amygdaloides and eight seedlings of Molinia caerulea. The schema of planting the perennials is shown in Fig. 3.

\section{Vegetation cover monitoring and vegetation maintenance on $\mathrm{BC} 1$ and $\mathrm{BC} 2$}

Plant growth was photographed regularly every two weeks during the vegetation seasons of 2018 in both BC. As part of the regular maintenance, weeds were continuously removed to maintain only the four types of perennials intended for both $\mathrm{BC}$. The vegetation cover was estimated for $\mathrm{BC} 1$ at the end of the evaluation period. The images perspective was adjusted using the open-source image processing package Fiji ImageJ (Schindelin et al., 2012) to obtain perpendicular images. Vegetation cover analysis and image segmentation was performed using the ImageJ WEKA plugin (Arganda-Carreras et al., 2017).

\section{Monitoring system configuration}

Soil water content was monitored in each of the two bioretention cells in the biofilter by time domain reflectometry (TDR) probes (CS635, Campbell Scientific, U.S.A.) connected to the reflectometer (TDR100, Campbell Scientific, U.S.A.). Six probes were installed in each BC (Fig. 2c), but due to the limited number of channels of the SDM8X50 multiplexer only the outer four TDR sensors were connected to the TDR unit in each BC. Water content probes were placed at a depth of $0.2 \mathrm{~m}$, below the bed of the bioretention cell at its lowest point. Values of actual volumetric water content $\theta_{v}$ were calculated using the Topp equation (Topp et al., 1980)

$$
\theta_{v}=-5.3 \cdot 10^{-2}+2.92 \cdot 10^{-2} K_{a}-5.5 \cdot 10^{-4} K_{a}^{2}+4.3 \cdot 10^{-6} K_{a}^{3}
$$

where $K_{a}$ is the apparent dielectric constant.

Water potential in each bioretention cell was automatically monitored using five tensiometers (T8, Meter Environment, Germany) which were installed by a special gauge auger at an angle of $45^{\circ}$ and safeguarded by a silicone gasket against the bypass flow along the probe body. The depths of measurement points of the particular tensiometers (the ceramic cup) were 12 cm (T8 1), $13 \mathrm{~cm}$ (T8 2), $21 \mathrm{~cm}$ (T8 3), $21 \mathrm{~cm}$ (T8 4), $25 \mathrm{~cm}$ (T8_5) in BC1 and $17 \overline{\mathrm{cm}}$ (T8_6), $13 \mathrm{~cm}$ (T8_7), $20 \mathrm{~cm}$ (T8_8), 25 cm (T8_9), $19 \mathrm{~cm}$ (T8_10) in BC2 below the surface. Additionally, water potential was sensed by two potential meters (MPS-6, Meter Environment, Germany) in each BC placed at a depth of $0.10 \mathrm{~m}$ below the bed of the bioretention cell at its deepest point. The interval for water content, tensiometers and water potential measurements was 6 minutes. The ultrasonic water level sensor (US1200, Fiedler AMS, Ltd., Czech Republic) was mounted on a metal frame in the middle of a bioretention cell at a height of $70 \mathrm{~cm}$ and records the water level during the BC's ponding in a two-minute step. Rainfall was measured by a heated tipping bucket rain gauge with a $200 \mathrm{~cm}^{2}$ collection area, resolution of $0.1 \mathrm{~mm}$, and a time step of $1 \mathrm{~min}(52202, \mathrm{R}$. M. Young, USA). Outflow from each bioretention cell was directed into a tipping bucket flowmeter, (PF500 flowmeter, Fiedler AMS, Ltd., Czech Republic) with 1-min intervals of pulse collections. The outflow rate of less than $0.5 \mathrm{~m}^{3} \cdot \mathrm{h}^{-1}$ has a linear function, according to the manufacturer, the volume per tip is $610 \mathrm{~mL}$ in $\mathrm{BC} 1 \mathrm{~mL}$ and $615 \mathrm{~mL}$ in $\mathrm{BC} 2$.
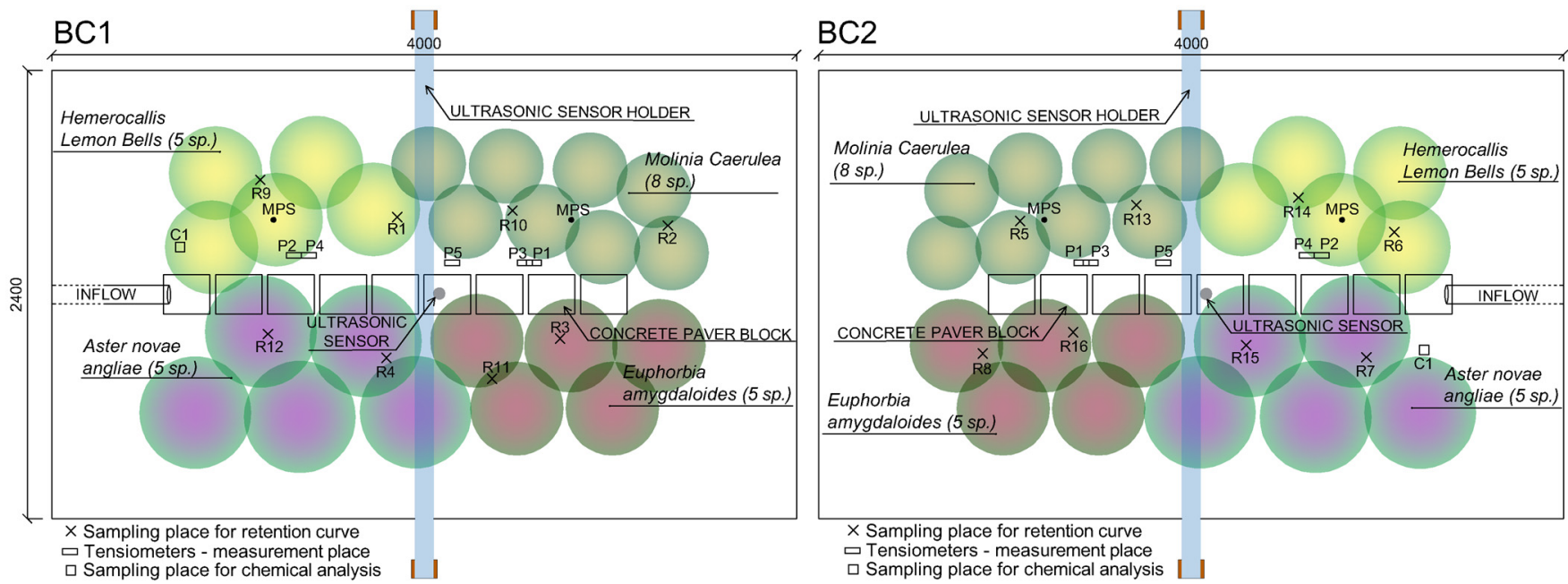

Fig. 3. Schema of experimental bioretention cells shown as plant layout, sampling places and location of tensiometers. The rectangles show the lower part of tensiometers T8_1-T8_10 as a measurement place. The crosses show the place of sampling undistributed samples for retention curve measurement. The square shows the sampling place of a distributed sample for chemical analyses measurement. 


\section{Physical and hydraulic properties of the biofilter as determined in the laboratory}

Soil hydraulic conductivity and water retention in the biofilter depends mainly on the soil's grain size distribution. Grain size analysis was performed by a combination of sieving and Casagrande's hydrometer methods (Casagrande, 1934) for particles smaller than $2 \mathrm{~mm}$. The dry bulk density was determined as a ratio of the weight of the dry sample to the total volume of the dry sample. Particle size distribution of the biofilter was the mass fraction of clay $(<0.002 \mathrm{~mm}), 12 \%$, the mass fraction of silt $(0.002-0.05 \mathrm{~mm}), 14 \%$, and the mass fraction of sand $(0.05-2 \mathrm{~mm}), 74 \%$. Particle size distribution of the biofilter media is presented in Fig. S3. According to the percentage of clay, silt and sandy particles, the soil was classified as sandy loam according to the USDA soil particles size triangle diagram (Soil Survey Manual, 2017). The dry bulk density of biofilter soil is $2563 \mathrm{~kg} \cdot \mathrm{m}^{-3}$. The $\mathrm{pH}$ was 7.2 and the final value of electric conductivity (EC) of the soil extract was 277 $\mu \mathrm{S} \cdot \mathrm{cm}^{-1}$ as measured by the EC probes. Saturated hydraulic conductivity was determined on three samples packed in cylinders with a diameter of $5 \mathrm{~cm}$ and a height of $6 \mathrm{~cm}$. The saturated hydraulic conductivity of the biofilter was measured by a constant head method on these sample places in the Tempe Cell (Reginato and Bavel, 1962). The gradient of the hydraulic head was set to 1.0 and a steady state flow rate of upward flow was determined. Measurements were conducted three times on each sample. The saturated hydraulic conductivity of the biofilter measured on samples in the laboratory $\left(K_{\text {slab }}\right)$ was $1.3 \cdot 10^{-4}$ $\mathrm{m} \cdot \mathrm{s}^{-1}$. Retention curves were measured on the undisturbed samples taken from the biofilter in the 10-cm-depth below the surface. Two batches of samples were taken from both BCs in 2018 , the first batch was collected before vegetation season, on June 6 , and the second after vegetation season, on November 11. Samples were taken into sample rings $6 \mathrm{~cm}$ in diameter at a height of $6 \mathrm{~cm}$. The main drainage branch of the retention curve was determined using a standard sand box and pressure extractor (Soil moisture Equipment Corp., Goleta, CA) instrumentation and method (Klute, 1986). Then, the van Genuchten parameters of the retention curve (van Genuchten, 1980) $\theta_{r}, \theta_{s}$, $\alpha$, and $n$ were determined by the non-linear least-squares method from measured retention data points using the RETC code (van Genuchten et al., 1991). The resulting retention curves are shown in Fig. 4 for the first and second samplings. It is evident from Fig. 4 that the shape of all retention curves is very similar. However, the saturated volumetric water content is slightly lower for samples taken after the vegetation season in both bioretention cells.

The parameters of the retention curves were fitted using the van Genuchten model (van Genuchten, 1980) and scaled according to Vogel et al. (1991) under the assumption of linearly variable hydraulic-properties to obtain representative retention curves. The van Genuchten parameters of the retention curve (van Genuchten, 1980) residual water content $\theta_{r}$, saturated water content $\theta_{s}$, and van Genuchten parameters $\alpha$ and $n$ are shown in Table 2 . The residual volumetric water content reaches

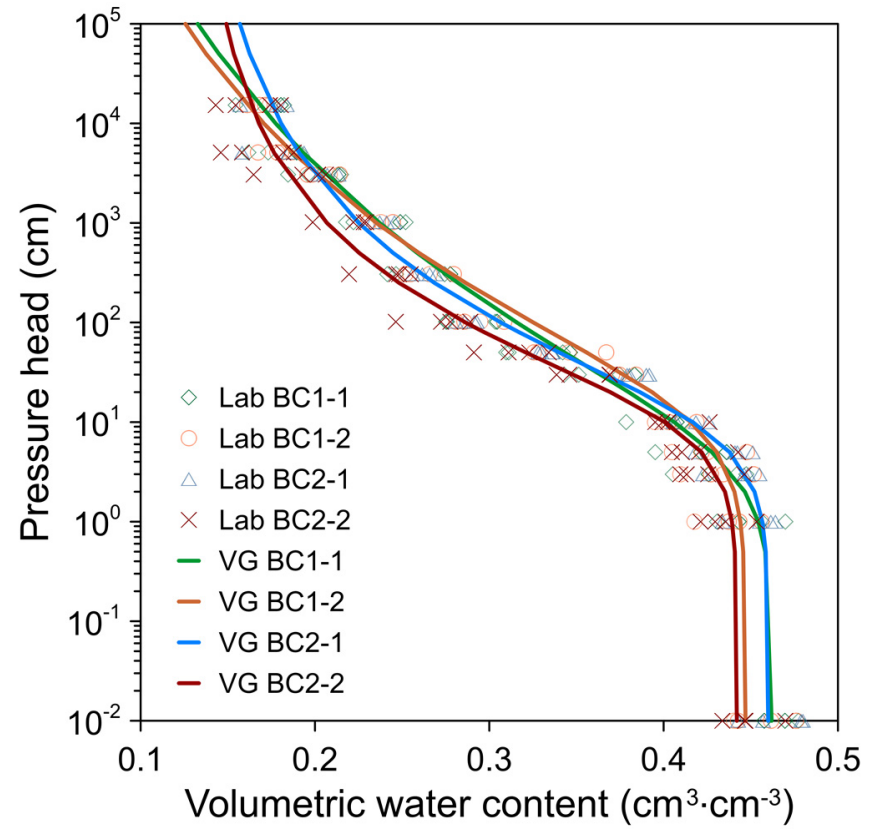

Fig. 4. Measured retention curve points and retention curves obtained by fitting a scaled van Genuchten model for the biofilter of the experimental BC: The symbols show the measured points of the retention line. Measurement $\mathrm{BC} 1 \_1$ and $\mathrm{BC} 2 \_1$ represents spring 2018 and measurement $\mathrm{BC} 1 \_2$ and $\mathrm{BC} 2 \_2$ represents fall 2018.

approximately the same values for the first and second samplings in $\mathrm{BC} 1$ and $\mathrm{BC} 2$. Saturated volumetric water content decreased after the vegetation season by 0.2 for both $\mathrm{BC}$.

\section{Rainfall-runoff analysis of BC1}

All experimental data were resampled to 15 -minute time steps due to the high volume of the data set. For the purpose of this study, each rainfall-runoff episode in $\mathrm{BC} 1$ began at the beginning of a rainfall and ended when the outflow rate dropped below $0.003 \mathrm{~mm} \cdot \mathrm{h}^{-1}$ (normalized to the roof area). Only episodes with a total rainfall amount greater than $1 \mathrm{~mm}$ were considered for further analysis. The methodology for rainfall-runoff analysis, mainly the definition of the beginning and end of a single rainfall-runoff follows Skala et al. (2020) and Snehota et al. (2021). In total, 17 rainfall-runoff episodes were evaluated for $\mathrm{BC} 1$. Each rainfall episode was paired with the induced outflow from the test beds and the basic rainfallrunoff characteristics, such as initial time, rainfall depth, maximal rainfall intensity, rainfall-runoff episode duration, runoff coefficient and maximal of peak outflow rate from $\mathrm{BC} 1$, were determined for each episode. The episode-based runoff coefficients were calculated as a fraction of the amount of runoff to the amount of precipitation received during the particular episode (i.e., several rainfall events might be considered as one episode when the outflow from $\mathrm{BC}$ is represented by one hydrograph).

Table 2. Measured residual water $\theta_{r}$, saturated water content $\theta_{s}$, and van Genuchten parameters $\alpha, n$.

\begin{tabular}{ccccc}
\hline & $\begin{array}{c}\theta_{r} \\
\left(\mathrm{~cm}^{3} \cdot \mathrm{cm}^{-3}\right)\end{array}$ & $\begin{array}{c}\theta_{r} \\
\left(\mathrm{~cm}^{3} \cdot \mathrm{cm}^{-3}\right)\end{array}$ & $\begin{array}{c}\alpha \\
\left(\mathrm{cm}^{-1}\right)\end{array}$ & $\begin{array}{c}n \\
(-)\end{array}$ \\
\hline BC1_1 & 0.000 & 0.462 & 0.199 & 1.126 \\
BC2_1 & 0.130 & 0.460 & 0.094 & 1.274 \\
BC1_2 & 0.024 & 0.447 & 0.078 & 1.159 \\
BC2_2 & 0.132 & 0.442 & 0.085 & 1.320 \\
\hline
\end{tabular}




\section{Ponding experiments on $\mathrm{BC} 2$}

Six ponding experiments were done on the $\mathrm{BC} 2$. The aim of the ponding experiments was to test the $\mathrm{BC}$ in controlled conditions with maximum loading. The influx to the bioretention cell was set to the level corresponding to the maximum rainfall with return period of 5-years for the experimental site. Such conditions were not likely to happen during the upcoming years of the experiment. The rainfall intensity is related to, in this case, a fictive $38 \mathrm{~m}^{2}$ of the roof area. The schema of the ponding experiments is shown in Fig. 5. BC2 was flooded with water from a storage tank using a controlled pump system. The flow rate was adjusted to the desired starting value by partly closing the valve on the hose and adjusting the rate of the pump. Flowrate was measured by an inductive flowmeter (FLONET FN20XX.1, ELIS, Czech Republic). Two ponding experiments simulating 15-minute rainfalls, with a high average intensity of $1.43 \mathrm{~mm} \cdot \mathrm{min}^{-1}$ and 120 -minute rainfall with a low average intensity of $0.296 \mathrm{~mm} \cdot \mathrm{min}^{-1}$, were conducted with each replicated three times. An automatic sampler (Sigma 900 MAX, Hach Company, USA) collected $250 \mathrm{~mL}$ of effluent outflow water every 5 minutes. Four consecutive samples were accumulated in one bottle resulting in the acquisition of one cumulative sample every 20 minutes. The automatic sampler collected outflow water for eight hours after the beginning of the ponding experiment. Electrical conductivity (EC), turbidity, $\mathrm{pH}$ and concentration of suspended solids (TSS) were measured on the outflow water samples. EC was determined by a conductivity electrode (Orion DuraProbe, Thermo Fisher Scientific, US), turbidity was determined by a turbidimeter (Orion AQ4500, Thermo Fisher Scientific, US), and $\mathrm{pH}$ was determined by a $\mathrm{pH}$ probe (Orion ROSS Ultra electrode, Thermo Fisher Scientific, US). For TSS determination, $200 \mathrm{~mL}$ water samples were filtered through $1.5 \mu \mathrm{m}$ glass fiber filter paper and then dried to $60^{\circ} \mathrm{C}$.

A digital camera (Fig. 5b) recorded the ponding experiments mainly for enhanced identification of the beginning of ponding. Despite there being no real rainfalls involved in the ponding experiments as water was delivered directly to the $\mathrm{BC}$ by pumping, we call these episodes simulated rainfalls throughout the text. The rainfall-runoff episodes were evaluated in a similar manner as in the case of natural rain episodes simulated on $\mathrm{BC} 1$, but, in this case, the sampling rate was one minute because of the shorter duration of the simulated rainfall episodes.

\section{Effective saturated hydraulic conductivity of bioretention cells}

The effective saturated hydraulic conductivity $K_{\text {seff }}$ of the two less conductive layers, biofilter and sand, was estimated from the in-situ ponding experiments of $\mathrm{BC} 1$ and from the rainfall-runoff episodes that produced ponding in the case of $\mathrm{BC} 2$. The effective saturated hydraulic conductivity of the biofilter and sand was calculated under the simplified assumption of a one-dimensional steady state and saturated vertical flow using Darcy's law, as suggested by Emerson and Traver, (2008). Fig. 6a shows the scheme for the simplified determination of $K_{\text {seff, with }} K_{\text {seff }}$ determined as:

$$
K_{\text {seff }}=\frac{L_{b}+L_{s}}{\frac{L_{b}}{K_{s b}}+\frac{L_{s}}{K_{s s}}}
$$

where $L_{b}$ is biofilter thickness, $L_{s}$ is sand layer thickness, $K_{s b}$ the saturated hydraulic conductivity of the biofilter, and $K_{s s}$ is the saturated hydraulic conductivity of sand. The length of the medium was determined as the thickness of the biofilter and of the sand layer, a total of $40 \mathrm{~cm}$. The saturated hydraulic conductivity of the biofilter was determined as:

$$
K_{s b}=\frac{q_{m} L}{\Delta H}
$$

where $q_{m}$ is flux density, $L$ is length of the whole medium, $\Delta H$ is the difference of the hydraulic head at the top and bottom of the two-layer column and flux density $q_{m}$ was determined as $q=Q / A$ from measured outflow $Q$. The gravel layer was not included in the calculation since it is assumed that it does not

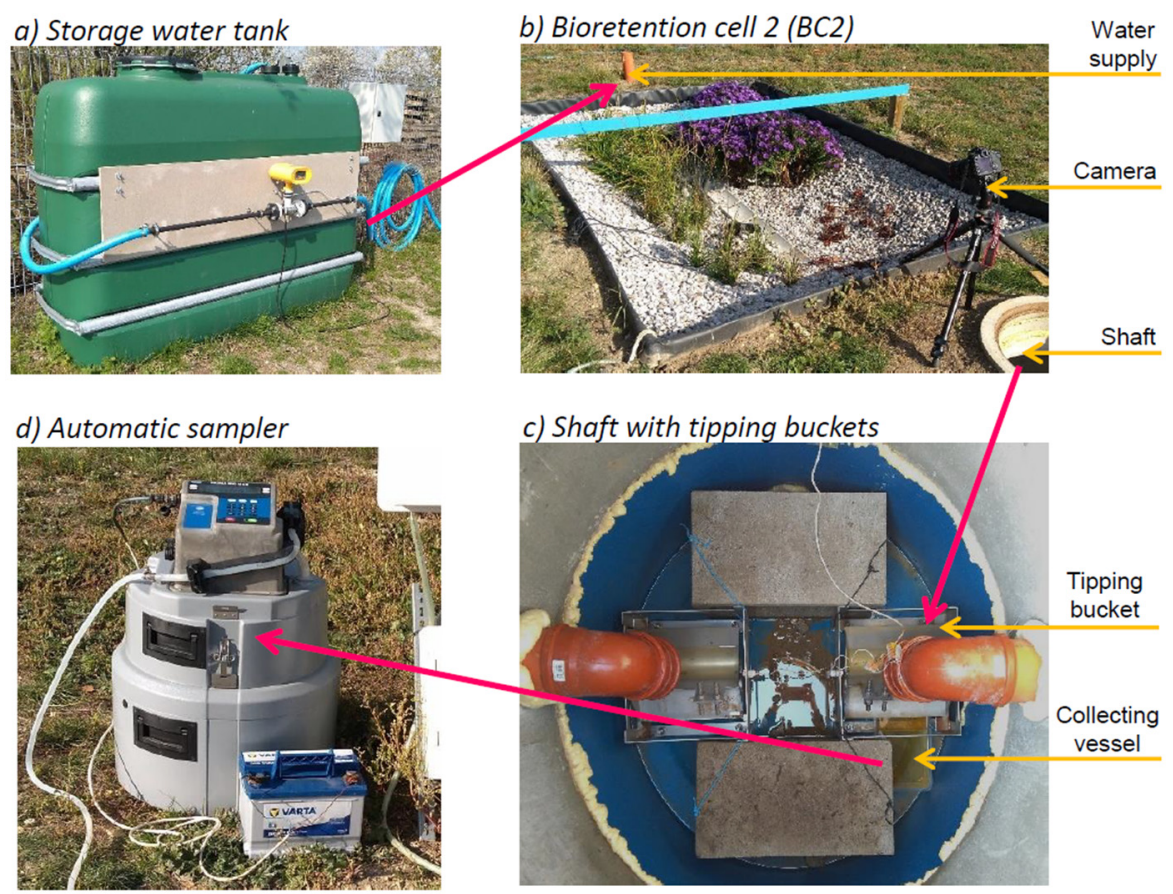

Fig. 5. Setup of ponding experiment: a) storage water tank; b) bioretention cell with camera; c) shaft with tipping bucket flowmeter; d) automatic sampler. 
a)

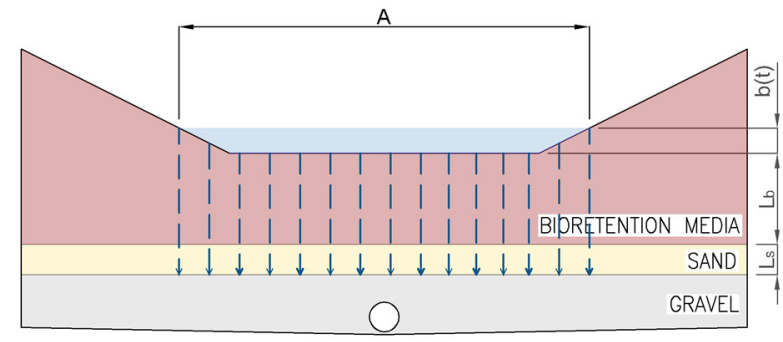

[!I!] Flow domain b)

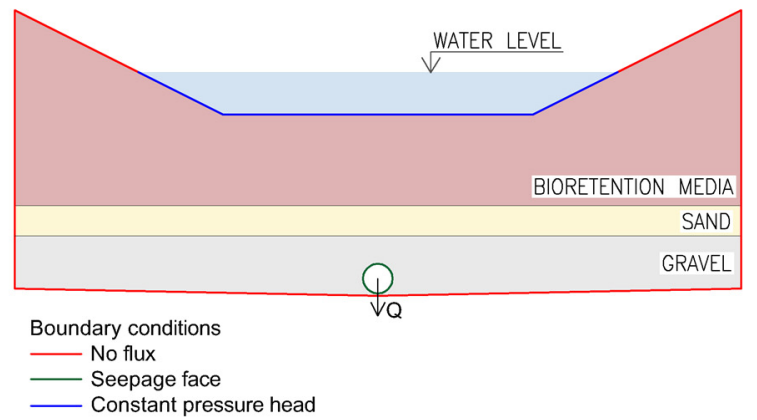

Fig. 6. a) Scheme for simplified determination of effective saturated hydraulic conductivity; b) the geometry of flow domain and boundary conditions for two-dimensional steady-state modelling of the flow in the bioretention cell (the scenario with a gravel layer).

Table 3. Soil hydraulic properties of three materials used for the layers in bioretention cell 1.

\begin{tabular}{lccccc}
\hline & $\begin{array}{c}\theta_{r} \\
\left(\mathrm{~cm}^{3} \cdot \mathrm{cm}^{-3}\right)\end{array}$ & $\begin{array}{c}\theta_{s} \\
\left(\mathrm{~cm}^{3} \cdot \mathrm{cm}^{-3}\right)\end{array}$ & $\begin{array}{c}\alpha \\
\left(1 \cdot \mathrm{cm}^{-1}\right)\end{array}$ & $\begin{array}{c}n \\
(-)\end{array}$ & $\begin{array}{c}K_{s} \\
\left(\mathrm{~cm}^{-1}\right)\end{array}$ \\
\hline Biofilter & 0.013 & 0.460 & 0.199 & 1.276 & $46.8^{*}$ \\
Sandy layer & 0.053 & 0.375 & 0.035 & 3.180 & 26.79 \\
Gravel layer & 0 & 0.293 & 0.1 & 2.500 & 3000 \\
\hline
\end{tabular}

Note: $*$ fitted parameter; $\theta_{r}$ is residual soil water contents, $\theta_{s}$ is saturated soil water contents, $K_{s}$ is saturated hydraulic conductivity, $\alpha$ and $n$ are empirical parameters.

restrict water flow. It is also assumed that there are capillary barrier forms close to zero at the bottom of the sand layer and pressure head. As another simplification, it is assumed that cross-sectional area $A$ is equal to the area of ponding water level a given time. Hydraulic conductivity was determined for the outflow rate achieved when the volumetric water content by TDR 1 achieved a value of $95 \%$ of maximal volumetric water content 0.34 . The TDR1 sensor, which is located at the inflow, always reached saturation from all four TDR probes last, so it was chosen as an indicator of the saturation status of the biofilter. The maximum volumetric water content measured by sensor TDR1 did not exceed value 0.36 , which is significantly less than $\theta_{s}$. The reason for not reaching $\theta_{s}$ can be seen in the presence of entrapped air in situ, which does not have higher saturation (Snehota et al., 2015).

In order to assess the validity of the assumption of dominantly vertical flow used for saturated hydraulic conductivity estimates, the two-dimensional simulation using HYDRUS-2D (Šimůnek et al., 2008) steady state water flow in the layers of the bioretention cell were analysed. The HYDRUS-2D code numerically solves the Richards equation for variably saturated water flow. Three ponding episodes with a constant level of ponding water were simulated until steady state conditions were reached. Episodes 7(I), 7(II) and 8, with different $K_{\text {seff, were }}$ chosen for the simulations. Value $K_{s b}$ was the fitted parameter. The calculated $K_{s b}$ values are higher than the $K_{s b f}$ values fitted in the model. Fig. 6b shows the flow domain geometry and boundary conditions. The mesh domain was generated with a target element size of $1 \mathrm{~cm}$ and automatic correction of points at the boundary curves was used to achieve finer discretization near the boundaries. For the initial condition, the hydrostatic distribution of the pressure head started from the lowest point of the flow domain where the pressure head was set to $-10 \mathrm{~cm}$. Hydraulic properties used in simulations of infiltration episodes in the bioretention cell are shown in Table 3. The soil hydraulic parameters for the sand layer were estimated using the Rosetta program (Schaap et al., 2001). The van Genuchten - Mualem (van Genuchten, 1980) function was used to characterize the shape of the soil water retention curve. As the saturated hydraulic conductivity and porosity of the gravel layer were estimated from the typical values for gravel, a fraction size of $8 / 16 \mathrm{~mm}$ was used (Filipovič et al., 2014; Freeze and Cherry, 1979).

$K_{s}$, shown in Table 3 , is the fitting parameter (in the following text in article as $K_{s b f}$ ) which was optimized until the flux density $q_{f}\left(\mathrm{~cm} \cdot \mathrm{h}^{-1}\right)$ value was equal (with a tolerance of $\pm 1 \%$ ) to the measured outflow $q_{m}$ that is shown in equation 4 . The flow rate was determined from the simulated flux density across the seepage face (in the drain) according to this equation:

$q_{f}=\frac{Q_{s f} L}{A}$

where $Q_{s f}\left(\mathrm{~cm}^{2} \cdot \mathrm{h}^{-1}\right)$ is seepage face flux, $L(\mathrm{~cm})$ is the length of the bioretention cell and $A\left(\mathrm{~cm}^{2}\right)$ is flow area. Two model scenarios were tested with one including a gravel layer and the other having no gravel layer.

\section{RESULTS \\ Bioretention cell BC1 \\ Rainfall-runoff analysis}

The total amount of rainfall during the observation period from June 18 to November 22, 2018, was 8320 liters, equals to $174.7 \mathrm{~mm}$ of rainfall depth related to the area of the roof (38 $\mathrm{m}^{2}$ ) and of the bioretention cell $\left(9.6 \mathrm{~m}^{2}\right)$. The total amount of water outflow from the $\mathrm{BC} 1$ in the same time interval was 7668 liters, which corresponds to a rainfall depth of $161 \mathrm{~mm}$. The variation in volumetric water content between the beginning and the end of the observed period was not significant, with a difference in the amount of water less than $1 \%(15 \mathrm{~L})$; therefore, the $14 \mathrm{~mm}$ difference between inflow and outflow can be attributed only to losses by evapotranspiration. For the episode base analysis, 17 rainfall-runoff episodes that occurred during the observation period were evaluated. An example of the dynamics 
of the onset of the rainfall-runoff episode (first 2.5 hours) is shown in Episode no. 7 in Fig. 7. Fig. 7a shows that outflow started in the $17^{\text {th }}$ minute after the beginning of the rainfall while the peak outflow occurred in the $32^{\text {th }}$ minute after the rainfall began. The peak flow was thus reduced by $86 \%$. The maximal height of ponding water recorded by the ultrasonic sensor in the middle of the bioretention was $103 \mathrm{~mm}$. Fig. 7b and Fig. 7c show that the biofilter was relatively wet before the rainfall. The biofilter was saturated to constant water content after approximately 1 hour and 12 minutes. When the level dropped to zero, the volumetric water content of tensiometer T8_4 decreased.
Table 4 shows the basic parameters for rainfall-runoff episodes in $\mathrm{BC} 1$. The highest rainfall and outflow depths and the highest peak rainfall intensity were recorded for episode no. 7 where the outflow volume reduction ranged from $75 \%$ to $97 \%$. Table 4 also lists the initial conditions for each rainfall-runoff episode in BC1. Specifically, the volumetric water content of the biofilter and the pressure head were measured at various depths of the biofilter. TDR 1 and TDR4 are situated closer to the inflow. The initial volumetric water content before the episodes in $\mathrm{BC} 1$ ranged from 0.31 and 0.33 . The lowest initial pressure head was recorded for the shallow tensiometer T8_2.
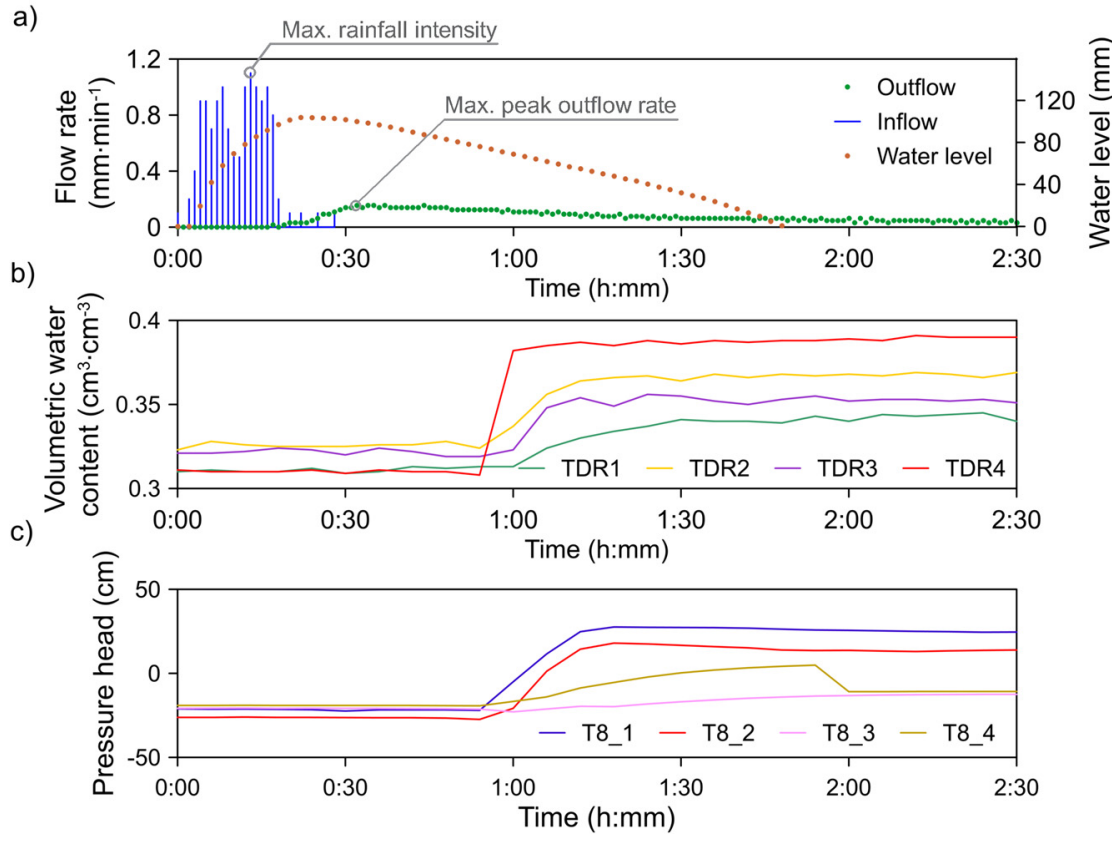

Fig. 7. Detailed analysis of start rainfall episode $7 \mathrm{in} \mathrm{BC} 1$. The outflow rate is related to the combined area $38 \mathrm{~m}^{2}$ of the roof and $\mathrm{BC}$ area of $9.6 \mathrm{~m}^{2}$ and expressed in $\mathrm{mm}$. Volumetric water content and pressure head shows the initial and actual boundary conditions of the biofilter. The tensiometers are placed at the following depths: T8_1(12 cm), T8_2 $(13 \mathrm{~cm}), \mathrm{T} 8 \_3(21 \mathrm{~cm}), \mathrm{T} 8 \_4(21 \mathrm{~cm})$.

Table 4. Basic parameters of the selected rainfall runoff episodes in $\mathrm{BC} 1$ and initial conditions in $\mathrm{BC} 1$ at the beginning of the episodes. Volumetric water content was measured by 4 TDR sensors placed in the middle of the biofilter. Pressure heads were measured by 5 tensiometers at different depths in the biofilter.

\begin{tabular}{|c|c|c|c|c|c|c|c|c|c|c|c|c|c|c|c|}
\hline & \multirow{4}{*}{$\begin{array}{c}\text { Initial } \\
\text { date } \\
\text { (dd.mm) }\end{array}$} & \multirow{4}{*}{$\begin{array}{l}\text { Rainfall } \\
\text { depth } \\
\text { (mm) }\end{array}$} & \multirow{4}{*}{$\begin{array}{l}\text { Max. rainfall } \\
\text { intensity } \\
\left(\mathrm{mm} \cdot \mathrm{min}^{-1}\right)\end{array}$} & \multirow{4}{*}{$\begin{array}{c}\text { Episode } \\
\text { duration } \\
\text { (min) }\end{array}$} & \multirow{4}{*}{$\begin{array}{l}\text { Runoff } \\
\text { coefficient } \\
(-)\end{array}$} & \multirow{4}{*}{$\begin{array}{l}\text { Max. of peak } \\
\text { outflow rate } \\
\left(\mathrm{mm} \cdot \mathrm{min}^{-1}\right)\end{array}$} & \multicolumn{9}{|c|}{ Initial conditions } \\
\hline \multirow{3}{*}{$\begin{array}{l}\text { Episode } \\
\text { No. }\end{array}$} & & & & & & & \multirow{2}{*}{\multicolumn{4}{|c|}{$\begin{array}{c}\begin{array}{c}\text { Volumetric water } \\
\text { Content }\left(\mathrm{cm}^{3} \cdot \mathrm{cm}^{-3}\right)\end{array} \\
\text { TDR: }\end{array}$}} & \multicolumn{5}{|c|}{ Pressure head $(\mathrm{cm})$} \\
\hline & & & & & & & & & & & & & T8 & & \\
\hline & & & & & & & 1 & 2 & 3 & 4 & 1 & 2 & 3 & 4 & 5 \\
\hline 1 & 22.06 . & 5.0 & 0.2 & 4575 & 0.89 & 0.012 & 0.31 & 0.31 & 0.33 & 0.31 & -24 & -27 & -24 & -22 & -11 \\
\hline 2 & 28.06 . & 6.7 & 0.1 & 4110 & 1.18 & 0.012 & 0.34 & 0.35 & 0.36 & 0.37 & -7 & -10 & -18 & -16 & -10 \\
\hline 3 & 06.07 . & 1.6 & 0.1 & 1335 & 0.39 & 0.012 & 0.31 & 0.30 & 0.32 & 0.29 & -34 & -39 & -25 & -23 & -19 \\
\hline 4 & 10.07 . & 6.6 & 0.1 & 4455 & 0.85 & 0.025 & 0.31 & 0.31 & 0.32 & 0.30 & -20 & -29 & -23 & -21 & -19 \\
\hline 5 & 21.07 . & 1.1 & 0.1 & 375 & 0.17 & 0.012 & 0.30 & 0.30 & 0.31 & 0.26 & -45 & -68 & -28 & -25 & -5 \\
\hline 6 & 02.08 . & 9.9 & 0.7 & 2460 & 0.71 & 0.049 & 0.28 & 0.29 & 0.29 & 0.24 & -72 & -165 & -34 & -30 & -3 \\
\hline 7 & 04.08 . & 23.3 & 1.1 & 4245 & 1.03 & 0.123 & 0.31 & 0.32 & 0.32 & 0.31 & -21 & -26 & -21 & -19 & _* \\
\hline 8 & 08.08 . & 2.2 & 0.1 & 2250 & 0.86 & 0.012 & 0.31 & 0.33 & 0.33 & 0.32 & -23 & -27 & -23 & -21 & -* \\
\hline 9 & 13.08 . & 2.5 & 0.4 & 1845 & 0.62 & 0.012 & 0.30 & 0.31 & 0.32 & 0.30 & -18 & -27 & -22 & -20 & -17 \\
\hline 10 & 24.08 . & 8.0 & 0.6 & 2595 & 0.7 & 0.025 & 0.28 & 0.30 & 0.31 & 0.26 & -47 & -25 & -27 & -25 & -17 \\
\hline 11 & 01.09 . & 16.3 & 0.3 & 5100 & 0.98 & 0.037 & 0.33 & 0.37 & 0.35 & 0.36 & -11 & -18 & -15 & -13 & -10 \\
\hline 12 & 07.09. & 1.4 & 0.1 & 1410 & 0.54 & 0.012 & 0.30 & 0.33 & 0.33 & 0.30 & -21 & -29 & -22 & -20 & -10 \\
\hline 13 & 21.09 . & 6.3 & 0.1 & 1380 & 0.48 & 0.025 & 0.25 & 0.30 & 0.30 & 0.23 & -42 & -412 & -28 & -25 & -24 \\
\hline 14 & 23.09 . & 11.6 & 1 & 765 & 0.47 & 0.037 & 0.33 & 0.33 & 0.34 & 0.38 & -18 & -21 & -17 & -15 & -14 \\
\hline 15 & 01.10 . & 1.6 & 0.1 & 405 & 0.37 & 0.012 & 0.30 & 0.32 & 0.33 & 0.28 & -24 & -31 & -22 & -20 & -19 \\
\hline 16 & 28.10 . & 18.2 & 0.1 & 4620 & 1.02 & 0.025 & 0.31 & 0.32 & 0.32 & 0.31 & -19 & -22 & -19 & -16 & -15 \\
\hline 17 & 02.11 . & 2.2 & 0.1 & 2025 & 0.96 & 0.012 & 0.33 & 0.33 & 0.34 & 0.32 & -19 & -20 & -19 & -16 & -16 \\
\hline
\end{tabular}

Note: *The missing data in tensiometer T8_5 in episodes 7 and 8 is caused by tensiometer leakage. 
Water content probes indicated volumetric water contents in the range of 0.22 to $0.40 \mathrm{~cm}^{3} \cdot \mathrm{cm}^{-3}$ during the entire monitored period for BC1 (Fig. 8). TDR 1 and TDR 4, placed closer to the inflow, reached lower values of volumetric water content, which is counterintuitive because it could be assumed that the soil closer to the inlet would receive water preferentially.

Fig. S4 shows pressure heads at different depths of the biofilter. It is remarkable that, despite the high temperatures and precipitation below the long-term average, the pressure heads dropped below water field capacity $(-330 \mathrm{~cm})$ only once in the biofilter of $\mathrm{BC} 1$ in September when a pressure head of $-414.4 \mathrm{~cm} \mathrm{H}_{2} \mathrm{O}$ was reached in the tensiometer located $13 \mathrm{~cm}$ below the surface of the biofilter. The pressure head monitoring showed that the plants were not subjected to water stress at any time during the observation period and, on the contrary, wet conditions prevailed.

\section{Vegetation growth}

Fig. S5 visually documents vegetation growth in $\mathrm{BC} 1$ at four time points of the growing season under study. The biofilter composed of sand, topsoil and compost in the current study proved optimal for the growth of perennials. The first bloomed perennials were Hemerocallis 'Lemon bells' in July. Euphorbia amygdaloides was not shown to be suitable for the BC as all the plants were withered after the vegetation season. In the evaluation period, Aster novae-angliae had the largest coverage. At the end of the growing season, the total average vegetation coverage of $\mathrm{BC} 1$ was approximately $15 \%$.

\section{BIORETENTION CELL BC2} Rainfall runoff-analysis

Table 5 shows the basic parameters for each ponding experiment in $\mathrm{BC} 2$, as well as the initial moisture condition of the biofilter prior to each experiment. The average peak flow reduction was $30 \%$ for 15 -minute ponding experiments PE1-
PE3 and 19\% for PE4-PE6. The runoff coefficient was the lowest in experiment PE1 which started at the driest conditions of the biofilter. In further ponding experiments, the biofilter was already wet and the runoff coefficients were close to one.

The main recorded parameters of the 15-minute ponding experiment PE1 are shown as an example of the ponding experiment in Fig. 9. Fig. 9a shows that outflow had already started five minutes after the beginning of inflow and the maximal of peak outflow rate occurred 17 minutes after the beginning of inflow. The water ponding level started in the fifth minute and dropped to the surface 23 minutes from the start of the rainfall. It can be seen from Figs. $9 b$ and $9 c$ that the soil was relatively dry at the beginning of the experiment. The lowest volumetric water content was 0.15 before the start of the simulated rainfall in PE1. In Fig. 9b, volumetric water content shows that the biofilter saturates after about 18 minutes from the start of the experiment. A detailed view of the start of the 15-minute ponding experiment ends after 6 hours and 26 minutes. Ponding experiments PE4-PE6 of 120-minutes duration were done after all three 15-minute experiments were completed. Consequently, the initial condition in the biofilter was significantly wetter than in experiment PE1. The average initial pressure head was about $-14 \mathrm{~cm}$ and the average initial volumetric water content was 0.3 . Volumetric water content in Fig. S6b shows that the biofilter saturates after about 18 minutes. The pressure heads shown in Fig. S6c are around zero $\mathrm{cm}$ at the time of the rainfall and fall back below zero after the end of the rainfall. Tensiometer T8_7 is not shown in graph $9 \mathrm{c}$ because it was aerated at the beginning of the experiment.

Fig. S7 shows the trend of volumetric water content in the biofilter during the evaluated period in $\mathrm{BC} 2$. The volumetric water content values in this biofilter are relatively low, as BC2 lacks a natural inflow from the roof. The lowest volumetric water content value of the biofilter was $0.14 \mathrm{~cm}^{3} \cdot \mathrm{cm}^{-3}$. Water content sensors TDR5 and TDR8 located closer to the inlet reached lower values. The same behavior was found with volumetric water content in $\mathrm{BC} 1$.

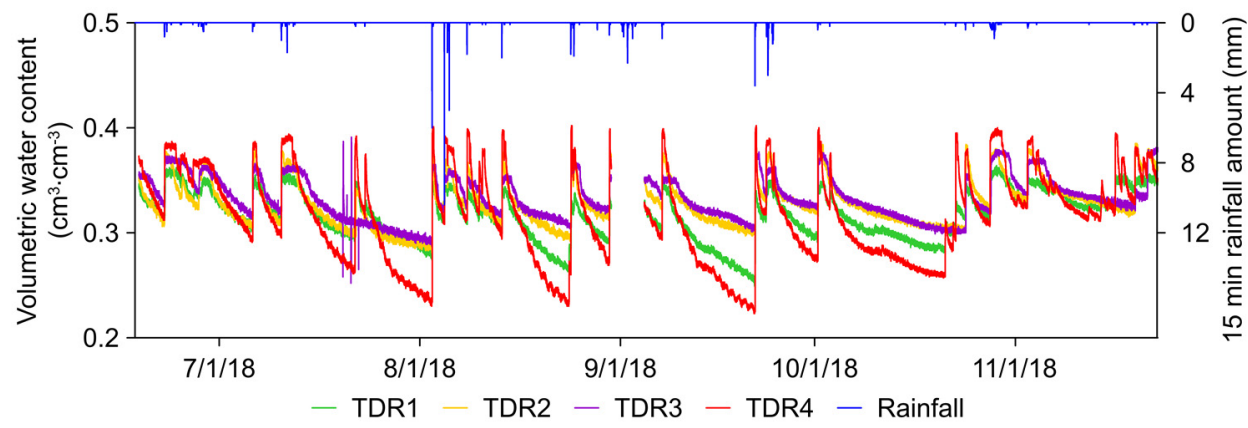

Fig. 8. Volumetric water content of the biofilter of the $\mathrm{BC} 1$.

Table 5. Basic parameters of the six ponding experiments conducted on $\mathrm{BC} 2$ and initial conditions in $\mathrm{BC} 2$ at the beginning of the episodes. Volumetric water content was measured by 4 TDR sensors placed in the middle of the biofilter. Pressure heads were measured by 5 tensiometers at different depths in the biofilter.

\begin{tabular}{|c|c|c|c|c|c|c|c|c|c|c|c|c|c|c|c|}
\hline \multirow{4}{*}{$\begin{array}{l}\text { Episode } \\
\text { No. }\end{array}$} & \multirow{4}{*}{$\begin{array}{c}\text { Initial } \\
\text { time }\end{array}$} & \multirow{4}{*}{$\begin{array}{c}\text { Rainfall } \\
\text { depth } \\
\text { (mm) }\end{array}$} & \multirow{4}{*}{$\begin{array}{l}\text { Max. simu- } \\
\text { lated rainfall } \\
\text { intensity } \\
\left(\mathrm{mm} \cdot \mathrm{min}^{-1}\right)\end{array}$} & \multirow{4}{*}{$\begin{array}{c}\text { Episode } \\
\text { duration } \\
\text { (min) }\end{array}$} & \multirow{4}{*}{$\begin{array}{c}\text { Runoff } \\
\text { coefficient } \\
(-)\end{array}$} & \multirow{4}{*}{$\begin{array}{l}\text { Max. of peak } \\
\text { outflow rate } \\
\left(\mathrm{mm} \cdot \mathrm{min}^{-1}\right)\end{array}$} & \multicolumn{9}{|c|}{ Initial conditions in $\mathrm{BC} 1$} \\
\hline & & & & & & & \multicolumn{4}{|c|}{$\begin{array}{l}\text { Volumetric water content } \\
\qquad\left(\mathrm{cm}^{3} \cdot \mathrm{cm}^{-3}\right)\end{array}$} & \multicolumn{5}{|c|}{ Pressure head (cm) } \\
\hline & & & & & & & \multicolumn{4}{|c|}{ TDR } & \multicolumn{5}{|c|}{ T8 } \\
\hline & & & & & & & 5 & 6 & 7 & 8 & 6 & 7 & 8 & 9 & 10 \\
\hline$\overline{\text { PE1 }}$ & 4.10. & 21.4 & 1.521 & 357.0 & 0.86 & 1.203 & 0.15 & 0.27 & 0.25 & 0.15 & -66 & -801 & -26 & -19 & -151 \\
\hline PE2 & 9.10 . & 21.8 & 1.534 & 1947.0 & 0.97 & 0.999 & 0.25 & 0.30 & 0.28 & 0.25 & -20 & -24 & -14 & -12 & -16 \\
\hline PE3 & 16.10 & 21.8 & 1.528 & 2103.8 & 0.97 & 0.999 & 0.24 & 0.29 & 0.28 & 0.26 & -29 & -28 & -17 & -15 & -19 \\
\hline PE4 & 31.10 . & 30.9 & 0.367 & 1884.2 & 0.98 & 0.316 & 0.28 & 0.32 & 0.31 & 0.29 & -14 & -19 & -12 & -10 & -15 \\
\hline PE5 & 6.11 & 32.2 & 0.401 & 2036.2 & 0.94 & 0.316 & 0.29 & 0.31 & 0.31 & 0.30 & -18 & -23 & -15 & -12 & -17 \\
\hline PE6 & 8.11 & 30.8 & 0.364 & 2382.2 & 0.94 & 0.282 & 0.34 & 0.34 & 0.31 & 0.31 & -14 & -9 & -3 & -3 & -4 \\
\hline
\end{tabular}


a)

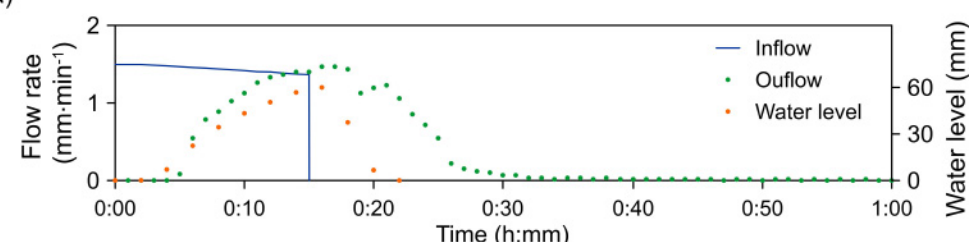

b)

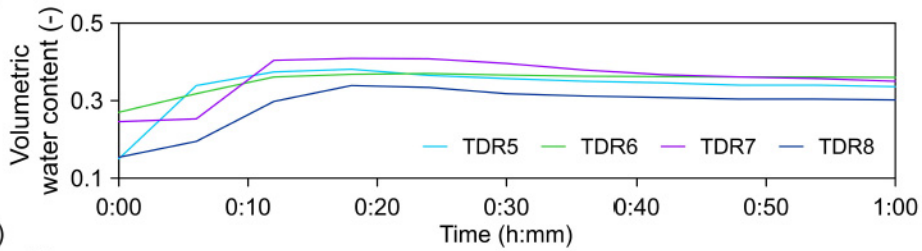

c)

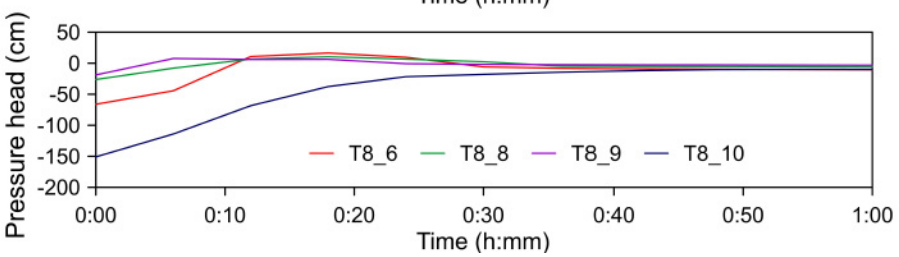

Fig. 9. Detailed view (first hour) of recorded: a) fluxes and water level; b) volumetric water contents of the biofilter; c) pressure heads in a ponding experiment conducted on BC2. Volumetric water content and pressure head show initial and actual conditions of the biofilter. The tensiometers are placed at the following depths: T8 $6(17 \mathrm{~cm})$, T8_7 $(13 \mathrm{~cm})$, T8_8 $(20 \mathrm{~cm})$, T8_9 $(25 \mathrm{~cm})$, T8_10 $(19 \mathrm{~cm})$.

Fig. S8 shows the trend of the pressure heads during the entire evaluated period in $\mathrm{BC} 2$. As expected, the pressure heads in $\mathrm{BC} 2$ were generally much lower than $\mathrm{BC} 1$. The shallowest tensiometer T8_7 was apparently leaking because the pressure head of the biofilter was outside the instrument's operating range. An attempt to refill the tensiometers was made on August 21 . The other shallow tensiometer T8_10 was not subjected to leakage despite the pressure heads approaching the lower limit of the measurement range. The pressure heads in all other tensiometers did not drop below water field capacity $(-330 \mathrm{~cm})$. The deepest tensiometer T8 9, placed $25 \mathrm{~cm}$ below the surface, indicated very wet conditions during the entire evaluated period.

\section{Influent and effluent water quality}

The water used for the ponding experiments was clean drinking water with a $\mathrm{pH}$ of $8.0, \mathrm{EC} 660 \mu \mathrm{S} \cdot \mathrm{cm}^{-1}$ and turbidity 0.99 NTU. Figs. 10a and 10b show pH values in the effluent during the first eight hours of the 15-minute and 120-minute ponding infiltration events. $\mathrm{pH}$ values of the effluent ranged between 7.8 and 8.6. The acidity of the effluent recorded during the ponding experiment exhibited an ascending trend in all experiments, with the exception of a sudden decrease at the beginning of the 120-minute ponding events. Figs. 10c and 10d show that EC in the effluent initially followed a descending trend the first hour for PE1-PE3 and the second hour for PE4PE6, but then the trend was reversed and the values steadily grew until the cessation of the outflow. The values of conductivity in the two-hour experiments were very similar for all three experiments. The EC reached higher maximal values in the 15 -minute experiments up to $2600 \mu \mathrm{S} \cdot \mathrm{cm}^{-1}$. Figs. $10 \mathrm{e}$ and $10 \mathrm{f}$ show turbidity values and Figs. $10 \mathrm{~g}$ and $10 \mathrm{~h}$ show the amount of total suspended solids. It can be seen from Figures $10 \mathrm{e}$ through $10 \mathrm{~h}$ that the concentration of suspended solids decreases with descending turbidity. The linear regression between turbidity and total suspended solids is significant. The average coefficient of determination $\mathrm{R}^{2}$ was 0.86 , therefore the turbidity is a good indicator of the TSS estimates. The total amount of suspended solids transported during the experiments with effluent water were $836 \mathrm{~g}(\mathrm{PE} 1=270 \mathrm{~g}, \mathrm{PE} 2=103.6 \mathrm{~g}$, PE3 $=169.9 \mathrm{~g}, \mathrm{PE} 4=77.1 \mathrm{~g}, \mathrm{PE} 5=91.2 \mathrm{~g}$, and PE6 $=124.4 \mathrm{~g}$ ).

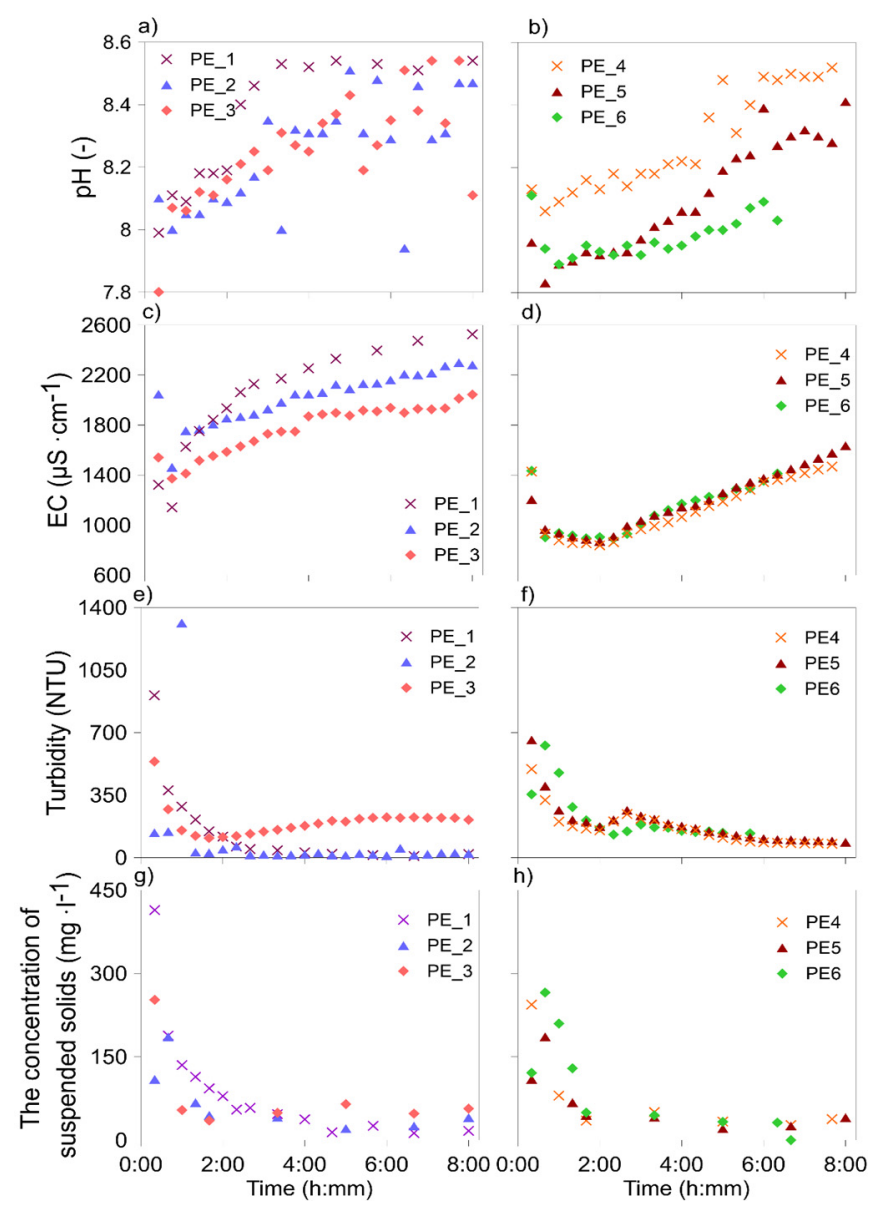

Fig. 10. Effluent water quality parameters during ponding experiments in the $\mathrm{BC} 2$. The left column shows: a) $\mathrm{pH}$; c) $\mathrm{EC}$; e) turbidity; g) the concentration of suspended solids for the 15 minute experiments. The right column of the graphs shows b) $\mathrm{pH}$; d) EC; f) turbidity; h) the concentration of suspended solids for the 120-minute experiment. 
Table 6. Calculated effective saturated hydraulic $K_{\text {seff }}$ conductivity of the three layers of BC1 (biofilter, sand and gravel) and calculated saturated hydraulic conductivity $K_{s b}$ of bioretention medium.

\begin{tabular}{|c|c|c|c|c|c|}
\hline Episode No. & $\begin{array}{c}\text { Number of rainfalls } \\
\text { in episodes }\end{array}$ & $\begin{array}{c}\text { Water } \\
\text { ponding level } \\
(\mathrm{cm}) \\
\end{array}$ & $\begin{array}{c}K_{\text {seff }} \\
\left(\mathrm{cm} \cdot \mathrm{h}^{-1}\right)\end{array}$ & $\begin{array}{c}K_{s b} \\
\left(\mathrm{~cm} \cdot \mathrm{h}^{-1}\right)\end{array}$ & $\begin{array}{c}\text { Average initial } \\
\text { volumetric water } \\
\text { content }\left(\mathrm{cm}^{3} \cdot \mathrm{cm}^{-3}\right)\end{array}$ \\
\hline 4 & $\mathrm{I}$ & 2.35 & 1.15 & 0.87 & 0.309 \\
\hline 6 & $\mathrm{I}$ & 2.62 & 3.43 & 2.66 & 0.273 \\
\hline \multirow{3}{*}{7} & $\mathrm{I}$ & 5.89 & 3.97 & 3.09 & 0.316 \\
\hline & II & 8.21 & 0.78 & 0.59 & 0.351 \\
\hline & III & 9.7 & 1.17 & 0.89 & 0.360 \\
\hline 8 & $\mathrm{I}$ & 2.08 & 1.18 & 0.89 & 0.319 \\
\hline 9 & I & 2.04 & 1.18 & 0.89 & 0.306 \\
\hline 10 & II & 3.1 & 1.09 & 0.83 & 0.354 \\
\hline \multirow{4}{*}{11} & I & 3.0 & 1.10 & 0.83 & \multirow{4}{*}{-} \\
\hline & II & 3.2 & 1.09 & 0.82 & \\
\hline & III & 9.2 & 1.47 & 1.12 & \\
\hline & IV & 3.8 & 1.09 & 0.79 & \\
\hline PE1 & $\mathrm{I}$ & 6.0 & 38.56 & 45.18 & 0.205 \\
\hline PE2 & $\mathrm{I}$ & 9.6 & 25.66 & 25.29 & 0.270 \\
\hline PE3 & $\mathrm{I}$ & 10.3 & 25.35 & 24.91 & 0.268 \\
\hline
\end{tabular}

\section{Hydraulic conductivity of the layers in $B C 1$}

Saturated hydraulic conductivity was evaluated for all episodes in which water ponding occurred and the saturated hydraulic conductivity of the biofilter could, therefore, be determined using Darcy's law. The water ponding level in Table 6 was determined after the saturation of the biofilter. The saturated hydraulic conductivity of the biofilter was higher at the lower initial volumetric water content. The average initial volumetric water content given in Table 6 was determined from the four TDR listed in Table 4.

\section{Modelling of steady state water flow in the biofilter}

Calculated $K_{s b}$, shown in Table 6, was used as an input parameter for the biofilter in the model of variably saturated flow. The difference in flux density in the two scenarios was less than $1 \%$. The results shown in Table 7 were determined by a gravel layer. The assumption of the vertical flow direction in the first two layers below the water surface, shown in Fig. S9, has been proven. In the unsaturated zone, water flows from a higher potential to a lower one. The highest velocities of water flow are achieved in the drainage gravel layer.

\section{DISCUSSION}

\section{Hydraulic conductivity of the biofilter layer}

It was expected that the saturated hydraulic conductivity of the biofilter layer may change in time due to soil consolidation, clogging root growth, and soil structure development. It is also known that hydraulic conductivity may vary between episodes due to different initial water content (Cislerova et al., 1988) and, correspondingly, different entrapped air content that may partly block the flow pathways (Snehota et al., 2010). The analysis of the ponding indeed confirmed that values of $K_{s}$ determined from natural rainfall-runoff varied between episodes in the case of $\mathrm{BC} 1$. Despite the limited number of episodes, the general pattern was that at lower pre-rainfall volumetric water content, the saturated hydraulic conductivity was higher during subsequent rainfall-runoff episode. For example, episode 6, with a lower initial volumetric water content of $0.273 \mathrm{~cm}^{3} \cdot \mathrm{cm}^{-3}$ led to an estimated $K_{s}$ of the filter layer $2.3 \cdot 10^{-6}$ $\mathrm{m} \cdot \mathrm{s}^{-1}$. On the contrary, the higher initial volumetric water content $0.354 \mathrm{~cm}^{3} \cdot \mathrm{cm}^{-3}$, prior to episode 10 when the volumetric water content led to the hydraulic conductivity of the filter layer, was approximately three times smaller.

In $\mathrm{BC} 1 K_{s}$ already decreased from the initial values $K_{\text {slab }}$ for the state immediately after filling the bioretention with biofilter material, during the winter before the first growing season. After vegetation season, there was visible subsidence of the soil by $5 \mathrm{~cm}$. This was probably due to the consolidation of the layers which also resulted despite the growth of vegetation (Archer et al., 2002; Hatt et al., 2009). This is in compliance with the findings of Le Coustumer et al. (2012) who showed that the actual hydraulic conductivity of each of the tested biofilters dropped to approximately half of the initial value (observations were made on biofilters with different periods of one-half to six years). Li and Davis (2008) observed decreasing hydraulic conductivity, where $K_{s}$ in their experiment dropped from $54 \pm 23$ and $72 \pm 46 \mathrm{~cm} \cdot \mathrm{h}^{-1}$ to less than $10 \mathrm{~cm} \cdot \mathrm{h}^{-1}$. Jenkins at al. (2010) tested biofilter $K_{s}$ for seven years and did not observe changes in $K_{s}$. The reduction of saturated hydraulic conductivity did not endanger the functioning of the BCs. Even after the reduction of the hydraulic conductivity of the filter layer, the ponding water always infiltrated within 24 hours in bioretention cell $\mathrm{BC} 1$, thus the functionality of the cell was maintained. Hydraulic conductivity $K_{s b}$ estimates, from ponding experiments with 15-minutes of simulated rain done on the second bioretention cell, were also lower by $12 \pm 10 \mathrm{~cm} \cdot \mathrm{h}^{-1}$ than the designed hydraulic conductivity while the value of $K_{s b}$ in $\mathrm{BC} 1$ decreased by $45 \pm 1 \mathrm{~cm} \cdot \mathrm{h}^{-1}$ compared to $K_{\text {slab. }}$. The water used for the ponding experiments was not polluted and there was almost no clogging. While the stormwater from the roof was not so clean, it is reasonable to assume that small particles could decrease $K_{s} \mathrm{BC} 1 . K_{s b}$ in $\mathrm{BC} 2$ was determined from extreme rainfall with higher intensity and longer durations and the trend of these rainfalls is different than the natural rainfall in $\mathrm{BC} 1$. Therefore, the $K_{s b}$ values determined in $\mathrm{BC} 2$ could be higher. Even after the decrease, the value of saturated hydraulic conductivity was in the range of $K$ recommended by Paus et al. (2016) in both bioretention cells.

\section{Rainfall - runoff characteristics}

The total volume of the effluent water from $\mathrm{BC} 1$ was $87 \%$ of the total amount of rain water supplied by the bioretention cell. The relatively low overall water retention was probably caused by low evaporation (due to the mulched surface) and transpire- 
Table 7. Comparison of flux density $q_{m}$ and fitted flux density $q_{f}$ and calculated $K_{s b}$ and modelled $K_{s b f}$ saturated hydraulic conductivity of the bioretention medium.

\begin{tabular}{lcccc}
\hline Event & $\begin{array}{c}q_{m} \\
\left(\mathrm{~cm} \cdot \mathrm{h}^{-1}\right)\end{array}$ & $\begin{array}{c}K_{s b f} \\
\left(\mathrm{~cm} \cdot \mathrm{h}^{-1}\right)\end{array}$ & $\begin{array}{c}q_{f} \\
\left(\mathrm{~cm} \cdot \mathrm{h}^{-1}\right)\end{array}$ & $\begin{array}{c}K_{s b f} / K_{s b} \\
(-)\end{array}$ \\
\hline Episode 7 (I) & 4.57 & 2.35 & 4.61 & 0.90 \\
Episode 7 (II) & 0.94 & 0.53 & 0.93 & 0.67 \\
Episode 8 & 1.24 & 0.60 & 1.24 & 0.76 \\
\hline
\end{tabular}

tion (because of the small leaf area of the plants) which were the only possible means of water loss in the bioretention cell that was isolated from the surrounding soil. In the studies listed in Table 1, the outflow reduction from BC ranges from 52 to $99 \%$ and the thicknesses of the biofilters range from 50 to 180 $\mathrm{cm}$. Thus, it is clear that the outflow reduction from BC is affected by both the composition of the biofilter and its thickness. Davis (2008), who isolated BC from surrounding soil with a polypropylene liner, 90 - and 129-cm-thick biofilters composed of $50 \%$ sand, $30 \%$ compost and $20 \%$ organic matter, obtained outflow reductions of $52 \%$ and $64 \%$ in these bioretention cells over two years. The runoff for the second and all subsequent ponding experiments done in $\mathrm{BC} 2$ was almost equal to the amount of the inflow water because the layers of the bioretention cell were very wet, at the water content corresponding to the hydrostatic distribution, as documented by the tensiometer readings. As expected, the first 15-minute ponding experiment, done after dry summer conditions, resulted in an outflow of $86 \%$ of the inflow water amount.

The peak outflow reduction in $\mathrm{BC} 1$ was between $75 \%$ to $97 \%$. Similar results were reported in other studies where the composition of the filter layer was different (Brown and Hunt, 2012; DeBusk and Wynn, 2011; Hunt et al., 2008). Other studies showed that reducing peak outflow is only effective at low and medium rainfall intensities (Brander et al., 2004; HolmanDodds et al., 2007; Hood et al., 2007). This complies with the result from $\mathrm{BC} 2$ where rainfall with higher intensity was simulated. The peak outflow reduction ranged from $13 \%$ to $34 \%$ in BC2.

The runoff coefficient was higher than 1 for episode no. 2 . The unintuitively high value can be explained by high antecedent water content prior to the episode. As Table 4 suggests, the measured water content of the biofilter before rainfall episode no. 2 was high. Initial pressure heads recorded by tensiometers were the highest of all rainfalls and above the equilibrium value that would correspond to hydrostatic distribution. Therefore, it is reasonable to assume that the likely redistribution of water in the profile was still active at the beginning of episode no. 2 and the bioretention cell released this water during this episode. The water, in this case, originated from the previous rainfall (depth of $0.4 \mathrm{~mm}$ ) that occurred approximately ten hours before the beginning of episode no. 2. Episodes 7 and 16, where the runoff coefficient was also slightly higher than 1, represent episodes with the highest rainfall depth, and with relatively wet soil prior to the rainfall. The runoff coefficient was less than 0.5 for episodes with a rainfall depth of $2 \mathrm{~mm}$.

Fig. 11 shows the dependency between inflow, outflow and maximal rainfall intensity. The natural rainfalls are shown by green bubbles and simulated rainfalls by purple bubbles. The values of the runoff coefficient are not dependent on the maximal rainfall intensity. In most episodes, the outflow is almost equal to the inflow.

The effect of the initial volumetric water content on the runoff coefficient was also shown by (Uber et al., 2018). The episodes with higher initial volumetric water content and higher rainfall depth produced a higher runoff coefficient (Fig. S10).

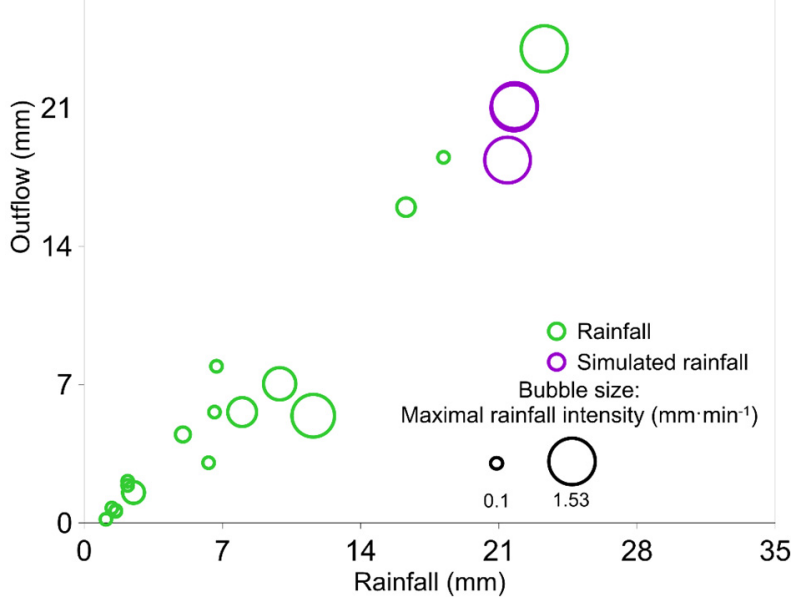

Fig. 11. Evaluation rainfall-runoff episodes in both bioretention cells from $18 / 6 / 2018$ to $22 / 11 / 2018$. The green circles show rainfall in $\mathrm{BC} 1$ and the purple circles show simulated rainfall episodes in $\mathrm{BC} 2$. The size of the circle shows the maximum rainfall intensity.

Changes of the steady state infiltration rate, dependent upon the initial volumetric water content, have also been shown in the study by Cislerova et al. (1988).

\section{Water regime of the biofilter layer}

The gravel mulch layer has proven to be an effective barrier for reducing evaporation and can be considered favorable for vegetation during the dry summer months. Despite the high air temperatures and low rainfall amounts, the minimal values of the pressure head were quite high $\left(-414.4 \mathrm{~cm} \mathrm{H}_{2} \mathrm{O}\right)$ in $\mathrm{BC} 1$, as recorded by a tensiometer $13 \mathrm{~cm}$ below the surface. Other tensiometers placed deeper in the filter layer did not drop below the field water capacity $\left(-330 \mathrm{~cm} \mathrm{H}_{2} \mathrm{O}\right)$. The minimal pressure head in $\mathrm{BC} 2$ was outside of the detection range of the tensiometers. Significantly lower water potentials recorded in $\mathrm{BC} 2$ were the consequence of the bioretention cell only receiving rain water directly falling on the area of the bioretention cell itself, except for the ponding experiments which were conducted towards the end of the examined season. The minimal volumetric water content monitored by TDR in the mid-depth of the biofilter was $0.14 \mathrm{~cm}^{3} \cdot \mathrm{cm}^{-3} \mathrm{BC}$. The biofilter of $\mathrm{BC} 1$ is significantly wetter with a minimal value of $0.220 \mathrm{~cm}^{3} \cdot \mathrm{cm}^{-3}$. The maximal volumetric water contents in the biofilter layers were nearly the same for both bioretention cells, slightly over 0 , which is less than the $\theta_{s}$ content of the biofilter that is 0.46 $\mathrm{cm}^{3} \cdot \mathrm{cm}^{-3}$. The reason why $\theta_{s}$ was never reached can be explained by the air entrapment in the soil pores where air content can easily reach over $10 \%$, even in homogeneous sand (Princ et al., 2020). The other reason for TDR not reaching the saturated 
water content can be the use of the general Topp equation (Topp et al., 1980) for TDR probes. A calibration curve due Topp et al, (1980) may not exactly represent the soil used as biofilter. However, the Topp equation generally performs very well in sandy loam soil (Zhu et al., 2019), therefore accuracy is expected to be high. (Bortolini and Zanin, 2018, 2017) used a similar soil mix of $50 \%$ sand, $25 \%$ topsoil and $25 \%$ organic matter and measured the same volumetric water content in the bioretention cell as ranging between 0.2 and $0.4 \mathrm{~cm}^{3} \cdot \mathrm{cm}^{-3}$ during rainfall.

It is notable and unintuitive that the first reaction of any of the TDR probes to the rainfall starts significantly later than the first outflow from when the BC occurs. This can be documented in the example in Fig. 7 which shows that the reaction of the TDR probes and tensiometers is delayed from the first outflow by 34 minutes. This can be caused by water preferentially starting to infiltrate close to the inlet and under the concrete tiles in the center of the bioretention cell between the tensiometers and TDR probes.

\section{Vegetation growth in the bioretention cells}

Aster novae-angliae, Hemerocallis and Molinia caerulea perennial plants performed very well in both bioretention cells, which is in compliance with the findings of Bortolini and Zanin (2018). The same three perennials in BCl were also able to adapt to the drier conditions in $\mathrm{BC} 2$. The fourth species planted in both bioretention cells under the study, Euphorbia amygdaloydes, was not proven to be suitable for bioretention cell conditions in the current study as they withered in both BCs.

\section{Effluent quality}

The TSS concentrations recorded during the ponding experiments in the effluent from $\mathrm{BC} 2$ were very high. The mean effluent TSS concentration reported by Shrestha (2018) was 8.9 $\mathrm{mg} \cdot \mathrm{L}^{-1}$, significantly less than in our case where the mean TSS was $104 \mathrm{mg} \cdot \mathrm{L}^{-1}$. Better retention of TSS by the bioretention cell in the study of Shrestha (2018) can be due to the greater depth of the sand layer. Li and Davis (2009) recorded a TSS concentration at inlet water of $66 \mathrm{mg} \cdot \mathrm{L}^{-1}$ and were reduced to 6 $\mathrm{mg} \cdot \mathrm{L}^{-1}$ at outflow. Also, the next study by Hunt et al. (2008) showed TSS reducing on the outflow from 50 to $20 \mathrm{mg} \cdot \mathrm{L}^{-1}$. Normally reported TSS load reduction ranges from 60 to $97 \%$ (DeBusk and Wynn, 2011; Roseen et al., 2006). Pure, drinking water, without near-zero TSS was used at the inlet of the current experiment on $\mathrm{BC} 2$ therefore the source of TSS can be in the mulch, biofilter, sand or gravel layer. The values of TSS are higher at the beginning of the outflow during the ponding experiments. Interestingly, the time development of turbidity and TSS are similar for two different types of ponding experiments with (15-minutes and 120-minutes). To explain the high TSS, the BC layers were additionally sampled in fall 2021 and tested for actual fraction of fine particles. The resulting percentage of particles smaller than $0.05 \mathrm{~mm}$ (clay and silt) was $25 \%$ in the biofilter and $9 \%$ in the sand layer. The requirements for fraction of fine particles vary in the literature. Due to FAWB (2009) guidelines, the maximal percentage of fines particles in biofilter should be relatively low only $3 \%$. Relatively high fraction of fines particles in could cause high TSS values in the effluent. Thus, the main reason for high TSS in the effluent is probably improperly washed sand in the filter layer. In the Czech national technical standard TVN 759011 (Kabelkova et al., 2013), the percentage of clay particles in the biofilter is much higher in the range from $10 \%$ to $30 \%$. Some standards do not specify the exact grain size distribution of the biofilter but only the percentage of sand, compost and topsoil. Some standards do not specify the exact maximal percentage of fine particles in biofilter, but only composition the percentage of sand, compost and topsoil components. In all studies listed in Table 1, the percentage of fine particles in the biofilter is always higher than $3 \%$. For example, Brown and Hunt (2012) and Olszewski and Davis (2012) specify a percentage of fine particles in biofilter of up to $46 \%$ in their studies. This criterion is still not properly defined and is still missing in many standards.

The presence of compost probably increased the EC of the effluent, which is in agreement with the findings of Tahvoven (2018) who detected the electrical conductivity of the effluent reaching $2000 \mu \mathrm{S} / \mathrm{cm}$ at the start of the heavy rainfall episodes and showed a declining trend after EC precipitation. High EC values after the beginning of rainfall were also observed on the effluents from the BC study by Roseen et al. (2006). In the case of experiments conducted on $\mathrm{BC} 2$, the $\mathrm{EC}$ in the runoff was declining during the time of the ponding experiment and was followed by a period of an electrical conductivity increase when water was draining freely from the soil. This trend might reflect the origin of the drained water. When the ponding is happening at the surface, water, driven by a high gradient, flows freely mainly via the inter-aggregate pores, whereas after the ponding, when soil becomes unsaturated, water is also being drained from the intra-aggregate pores. The latter represents water with a much higher residence time and, therefore, it is more mineralized.

\section{CONCLUSIONS}

Two intensively instrumented outdoor test beds have been constructed to evaluate the short-term and long-term performance of the bioretention cell with a focus on the performance of the biofilter. The functionality of the set-up was proven during the first growing season. The overall runoff coefficient during the entire monitoring period was relatively high, at a value of 0.88 for $\mathrm{BC} 1$ supplied with natural rainfalls. An episode-based analysis shows that a significant reduction of the outflow was achieved for only the smallest rainfall episodes. The saturated hydraulic conductivity of the biofilter layer in the bioretention cell that was supplied by natural rain decreased significantly from the designed value, due to consolidation during the monitoring period. $\mathrm{BC} 2$, supplied with water during the limited number of ponding experiments, did not show a significant decline of hydraulic conductivity. Unexpectedly high levels of turbidity and TSS were recorded during the ponding experiments on $\mathrm{BC}$. The high TSS values were probably due to the high percentage of fine particles in the biofilter and in the sand layer. The dynamics of TSS and $\mathrm{pH}$ and EC in the effluent during repeated ponding experiments exhibited repeating dynamic patterns in most experiments.

Due to capillary disconnection from the surrounding soil and the presence of the mulch layer at the surface, the moisture of the biofilter layer was high during the entire growing season in the bioretention cell supplied with natural rain. Such moisture conditions supported growth of three out of the four species of perennial plants. However, the most dynamic growth was recorded in Aster novae-angliae.

Monitoring of the experimental bioretention cells will continue using the methodology developed in this study to assess the mid- and long-term changes of the bioretention performance. The detailed data on water content, pressure heads and runoff are available for further interpretation by numerical modelling. 
Acknowledgement. This work has been supported by the Czech Science Foundation, under Grant no. 17-21011S. It was also supported by the Grant Agency of the Czech Technical University in Prague, SGS20/157/OHK1/3T/11.

\section{REFERENCES}

Aravena, J., Dussaillant-Jones, A., 2009. Stormwater infiltration and focused recharge modeling with finite-volume twodimensional Richards equation: application to an experimental rain garden. Journal of Hydraulic Engineering, 135, 12. https://doi.org/10.1061/ASCEHY.1943-7900.0000111

Arganda-Carreras, I., Kaynig, V., Rueden, C., Eliceiri, K., Schindelin, J., Cardona, A., Seung, H., 2017. Trainable Weka Segmentation: A machine learning tool for microscopy pixel classification. Bioinformatics, 33, 15, 2424-2426. https://doi.org/10.1093/bioinformatics/btx180

Archer, N.A.L., Quinton, J.N., Hess, T.M., 2002. Belowground relationships of soil texture, roots and hydraulic conductivity in two-phase mosaic vegetation in South-east Spain. Journal of Arid Environments, 52, 535-553. https://doi.org/10.1006/jare.2002.1011

Austin, G., 2012. Design and performance of bioretention beds for removal of stormwater contaminants. Journal of Green Building, 7, 1, 17-27.

Bioretention Manual, 2003. Department of Environmental Resources, Maryland. Environmental Services Division, Department of Environmental Resources, The Prince George's County, Maryland.

Booth, D., Hartley, D., Jackson, C. 2002. Forest cover, impervious-surface area, and the mitigation of stormwater impacts. Journal of the American Water Resources Association, 38, 835-845. https://doi.org/10.1111/j.1752-1688.2002.tb01000.x

Bortolini, L., Zanin, G., 2017. The experimental and educational rain gardens of the Agripolis Campus (north-east Italy): preliminary results on hydrological and plant behavior. Acta Horticulturae, 531-536. https://doi.org/10.17660/ActaHortic. 2017.1189.106

Bortolini, L., Zanin, G., 2018. Hydrological behaviour of the rain gardens and plant suitability: A study in the Veneto plane (north-eastern Italy) conditions. Urban Forestry \& Urban Greening, 37. https://doi.org/10.1016/j.ufug.2018. 07.003

Brander, K., Owen, K., Potter, K., 2004. Modeled impacts of development type on runoff volume and infiltration performance. Journal of the American Water Resources Association, 40, 961-969. https://doi.org/10.1111/j.17521688.2004.tb01059.x

Brown, R., Hunt, W., 2012. Improving bioretention/Biofiltration performance with restorative maintenance. Water Science and Technology, 65, 361-367. https://doi.org/10.2166/wst.2012.860

Casagrande, A., 1934. Die Aräometer-Methode zur bestimmung der Kornverteilung von Böden und anderen Materialien. Julius Springer, Berlin. (In German.)

Cislerova, M., Simunek, J., Vogel, T., 1988. Changes of steady state infiltration rate in recurrent ponded infiltration experiments. Journal of Hydrology, 104, 1-16. https://doi.org/10.1016/0022-1694(88)90154-0

Coffman, L.S., France, R.L., 2002. Low-impact development: an alternative stormwater management technology. In: Handbook of Water Sensitive Planning and Design, pp. 97123.

Davis, A., 2008. Field performance of bioretention: Hydrology impacts. Journal of Hydrologic Engineering, 13, 90.
https://doi.org/10.1061/(ASCE)1084-0699(2008)13:2-90

DeBusk, K.M., Wynn, T.M., 2011. Storm-water bioretention for runoff quality and quantity mitigation. Journal of Environmental Engineering-ASCE, 137, 800-808. https://doi.org/10.1061/(asce)ee.1943-7870.0000388

Dietrich, A., Yarlagadda, R., Gruden, C., 2017. Estimating the potential benefits of green stormwater infrastructure on developed sites using hydrologic model simulation. Environmental Progress \& Sustainable Energy, 36, 2, 557-564. https://doi.org/10.1002/ep.12428

Dietz, M.E., 2007. Low impact development practices: A review of current research and recommendations for future directions. Water Air Soil Pollution, 186, 351-363. https://doi.org/10.1007/s11270-007-9484-z

Dietz, M.E., Clausen, J.C., 2005. A field evaluation of rain garden flow and pollutant treatment. Water Air Soil Pollution, 167, 123-138. https://doi.org/10.1007/s11270-0058266-8.

Emerson, C.H., Traver, R.G., 2008. Multiyear and seasonal variation of infiltration from storm-water best management practices. Journal of Irrigation and Drainage Engineering, 134, 598-605. https://doi.org/10.1061/(asce)0733-9437 (2008)134:5(598)

Facility for Advancing Water Biofiltration (FAWB), 2009. Adoption Guidelines for Stormwater Biofiltration Systems. Facility for Advancing Water Biofiltration, Monash University, June 2009.

Filipović, V., Mallmann, F., Coquet, Y., Simunek, J., 2014. Numerical simulation of water flow in tile and mole drainage systems. Agricultural Water Management, 146, 105114. https://doi.org/10.1016/j.agwat.2014.07.020

Fletcher, T.D., Shuster, W., Hunt, W.F., Ashley, R., Butler, D., Arthur, S., Trowsdale, S., Barraud, S., Semadeni-Davies, A., Bertrand-Krajewski, J.L., Mikkelsen, P.S., Rivard, G., Uhl, M., Dagenais, D., Viklander, M., 2015. SUDS, LID, BMPs, WSUD and more - The evolution and application of terminology surrounding urban drainage. Urban Water Journal, 12, 525-542. https://doi.org/10.1080/1573062x.2014.916314

Freeze, R.A., Cherry, J.A., 1979. Groundwater. Prentice-Hall, Englewood Cliffs, N.J.

Gulbaz, S., Kazezyilmaz-Alhan, C.M., 2017. Experimental investigation on hydrologic performance of LID with rainfall-watershed-bioretention system. Journal of Hydrologic Engineering, 22, 10. https://doi.org/10.1061/(asce)he.19435584.0001450

Hatt, B.E., Fletcher, T.D., Deletic, A., 2009. Hydrologic and pollutant removal performance of stormwater biofiltration systems at the field scale. Journal of Hydrology, 365, 310321. https://doi.org/10.1016/j.jhydrol.2008.12.001

Hollis, G.E., 1977. Water yield changes after the urbanization of the canon's brook catchment, Harlow, England. Hydrological Sciences Bulletin, 22, 1, 61-75. DOI: 10.1080/02626667709491694

Holman-Dodds, J., Bradley, A., Potter, K., 2007. Evaluation of hydrologic benefits of infiltration based urban storm water management. Journal of the American Water Resources Association, 39, 205-215. https://doi.org/10.1111/j.17521688.2003.tb01572.x

Hood, M., Clausen, J., Warner, G., 2007. Comparison of stormwater lag times for low impact and traditional residential development. Journal of the American Water Resources Association, 43, 1036-1046. https://doi.org/10.1111/j.17521688.2007.00085.x

Houdeshel, C.D., Hultine, K.R., Johnson, N.C., Porneroy, C.A., 2015. Evaluation of three vegetation treatments in bioreten- 
tion gardens in a semi-arid climate. Landscape and Urban Planning, 135, 62-72. https://doi.org/10.1016/j.landurbplan. 2014.11.008

Huber, W.C., 1995. EPA storm water management modelSWMM. In: Singh, V.P. (Ed.): Computer Models of Watershed Hydrology. Water Resources Publications, pp. 783808.

Hunt, W., Smith, J., Jadlocki, S., Hathaway, J., Eubanks, P., 2008. Pollutant removal and peak flow mitigation by a bioretention cell in urban Charlotte, N.C. Journal of Environmental Engineering, 134, 5, 403. https://doi.org/10.1061/(ASCE)0733-9372(2008)134:5(403)

Imteaz, M.A., Nguyen, T., Kuok, K., 2015. Experimental and mathematical modelling study on clogging behaviour of bioretention systems. International Journal of Hydrology Science and Technology, 5. https://doi.org/10.1504/IJHST. 2015.069280

Jangorzo, N.S., Watteau, F., Schwartz, C., 2013. Evolution of the pore structure of constructed Technosols during early pedogenesis quantified by image analysis. Geoderma, 207, 180-192. https://doi.org/10.1016/j.geoderma.2013.05.016

Jenkins, J.K.G., Wadzuk, B.M., Welker, A.L., 2010. Fines accumulation and distribution in a storm-water rain garden nine years postconstruction. Journal of Irrigation and Drainage Engineering, 136, 862-869. https://doi.org/10.1061/ (asce)ir.1943-4774.0000264

Kabelkova, I., Stransky, D., Bares, V., 2013. TNV 759011 Hospodareni se srazkovymi vodami = TNV 759011 Sustainable stormwater management. Part 1: Choice of the drainage concept and of the technical solution. Vodní hospodářství, 63, 9, 289-294.

Kabisch, N., Korn, H., Stadler, J., Bonn, A., 2017. NatureBased solutions to climate change adaptation in urban Areas-Linkages between science. Policy and Practice, 1-11. https://doi.org/10.1007/978-3-319-56091-5 1

Klute, A., 1986. Water retention: Laboratory methods. In: Klute, A. (Ed.): Methods of Soil Analysis. Part 1. Physical and Mineralogical Methods. American Society of Agronomy, Soil Science Society of America, Wisc., pp. 635-662. https://doi.org/10.2136/sssabookser5.1.2ed.c26

Le Coustumer, S., Fletcher, T., Deletic, A., Barraud, S., Lewis, J., 2009. Hydraulic performance of biofilter systems for stormwater management: Influences of design and operation. Journal of Hydrology, 376, 16-23. https://doi.org/10.1016/j. jhydrol.2009.07.012

Le Coustumer, S., Fletcher, T.D., Deletic, A., Barraud, S., Poelsma, P., 2012. The influence of design parameters on clogging of stormwater biofilters: A large-scale column study. Water Res., 46, 6743-6752. https://doi.org/10.1016/j.watres.2012.01.026

Li, H., Davis, A.P., 2008. Urban particle capture in bioretention media. I: Laboratory and field studies. Journal of Environmental Engineering, 134, 409-418. https://doi.org/10.1061/ (asce)0733-9372(2008)134:6(409)

Li, H., Davis, A.P., 2009. Water quality improvement through reductions of pollutant loads using bioretention. Journal of Environmental Engineering, 135, 567-576. https://doi.org/ 10.1061/(asce)ee.1943-7870.0000026

Li, J., Zhao, R.S., Li, Y.J., Chen, L., 2018. Modeling the effects of parameter optimization on three bioretention tanks using the HYDRUS-1D model. Journal of Environmental Management, 217, 38-46. DOI: 10.1016/.jenvman.2018.03.078

Liao, K.-H., Deng, S., Tan, P., 2017. Blue-green infrastructure: New frontier for sustainable urban stormwater management. In: Greening Cities. Springer, pp. 203-226. https://doi.org/10.1007/978-981-10-4113-6_10

Marsalek, J., Barnwell, T., Geiger, W., Grottker, M., Huber, W., Saul, A., Schilling, W., Torno, H., 1993. Urban drainage systems: design and operation. Water Science and Technology, 27, 31-70. https://doi.org/10.2166/wst.1993.0291

Melbourne water, 2013. Water sensitive urban design guidelines. South Eastern Councils.

Muerdter, C., Wong C., LeFevre G., 2018. Emerging investigator series: The role of vegetation in bioretention for stormwater treatment in the built environment: pollutant removal, hydrologic function, and ancillary benefits. Environmental Science: Water Research \& Technology, 4, 592-612. DOI: 10.1039/C7EW00511C

Olszewski, J., Davis, A., 2012. Comparing the hydrologic performance of a bioretention cell with predevelopment values. Journal of Irrigation and Drainage Engineering, 139, 124130. https://doi.org/10.1061/(ASCE)IR.1943-4774.0000504

Paus, K.H., Muthanna, T.M., Braskerud, B.C., 2016. The hydrological performance of bioretention cells in regions with cold climates: seasonal variation and implications for design. Hydrology Research, 47, 291-304. https://doi.org/10. 2166/nh.2015.084

Princ, T., Fideles, H.M., Koestel, J., Snehota, M., 2020. The impact of capillary trapping of air on satiated hydraulic conductivity of sands interpreted by X-ray microtomography. Water, 12, 2, 445. https://doi.org/10.3390/w12020445

Qin, H., Li, Z., Fu, G., 2013. The effects of low impact development on urban flooding under different rainfall characteristics. Journal of Environmental Management, 129, 577585. https://doi.org/10.1016/j.jenvman.2013.08.026

Recanatesi, F., Petroselli, A., Ripa, M., Leone, A., 2017. Assessment of stormwater runoff management practices and BMPs under soil sealing: A study case in a peri-urban watershed of the metropolitan area of Rome (Italy). Journal of Environmental Management, 201, 6-18. https://doi.org/ 10.1016/j.jenvman.2017.06.024

Reginato, R., Bavel, C., 1962. Pressure cell for soil cores. Soil Science Society of America Journal, 26. https://doi.org/10.2136/sssaj1962.03615995002600010001x

Roseen, R., Ballestero, T., Houle, J., Avelleneda, P., Wildey, R., Briggs, J., 2006. Storm water low-impact development, conventional structural, and manufactured treatment strategies for parking lot runoff: performance evaluations under varied mass loading conditions. Journal of the Transportation Research Board, 1984, 135-147. https://doi.org/10.1177/0361198106198400113

Scalenghe, R., Ferraris, S., 2009. The first forty years of a Technosol. Pedosphere, 19, 40-52. https://doi.org/ 10.1016/s1002-0160(08)60082-x

Sere, G., Ouvrard, S., Magnenet, V., Pey, B., Morel, J.L., Schwartz, C., 2012. Predictability of the evolution of the soil structure using water flow modeling for a constructed Technosol. Vadose Zone Journal, 11, 13. https://doi.org/10. 2136/vzj2011.0069

Shrestha, P., 2018. Effects of different soil media, vegetation, and hydrologic treatments on nutrient and sediment removal in roadside bioretention systems. Ecological Engineering, 112. https://doi.org/10.1016/j.ecoleng.2017.12.004

Schaap, M., Leij, F., Van Genuchten, M., 2001. ROSETTA: A computer program for estimating soil hydraulic parameters with hierarchical pedotransfer functions. Journal of Hydrology, 251, 163-176. https://doi.org/10.1016/S0022-1694(01)00466-8

Schindelin, J., Arganda-Carreras, I., Frise, E., Kaynig, V., Longair, M., Pietzsch, T., Preibisch, S., Rueden, C., Saalfeld, S., Schmid, B., Tinevez, J.-Y., White, D., Hartenstein, V., 
Eliceiri, K., Tomancak, P., Cardona, A., 2012. Fiji: An Open-Source Platform for Biological-Image Analysis. Nature Methods, 9, 676-682. https://doi.org/10.1038/nmeth.2019

Skala, V., Dohnal, M., Votrubova, J., Vogel, T., Dusek, J., Sacha, J., Jelinkova, V., 2020. Hydrological and thermal regime of a thin green roof system evaluated by physicallybased model. Urban Forestry \& Urban Greening, 48, 126582. https://doi.org/10.1016/j.ufug.2020.126582

Snehota, M., Cislerova, M., Amin, M.H.G., Hall, L.D., 2010. Tracing the entrapped air in heterogeneous soil by means of magnetic resonance imaging. all rights reserved. Vadose Zone Journal, 9, 2, 373-384. https://doi.org/10.2136/vzj2009.0103

Snehota, M., Jelinkova, V., Sobotkova, M., Sacha, J., Vontobel, P., Hovind, J., 2015. Water and entrapped air redistribution in heterogeneous sand sample: Quantitative neutron imaging of the process. Water Resources Research, 51, 2, 13591371. https://doi.org/10.1002/2014WR015432

Snehota, M., Hanzlikova, J., Sobotkova, M., Moravcik, P., 2021. Water and thermal regime of extensive green roof test beds planted with sedum cuttings and sedum carpets. Journal of Soils and Sediments. https://doi.org/10.1007/s11368-02002778-x

Soil Survey Manual, 2017. USDA Handbook 18. Government Printing Office, Washington, D.C.

Šimůnek, J., van Genuchten, M.Th., Šejna, M., 2008. Development and applications of the HYDRUS and STANMOD software packages and related codes. Vadose Zone Journal, 7, 587-600. https://doi.org/10.2136/vzj2007.0077

Tahvonen, O., 2018. Adapting bioretention construction details to local practices in Finland. Sustainability, 10, 17. https://doi.org/10.3390/su10020276

Topp, G.C., Davis, J.L., Annan, P., 1980. Electromagnetic determination of soil water content: Measurements in coaxial transmission lines. Water Resources Research, 16, 574582. https://doi.org/10.1029/WR016i003p00574

Uber, M., Vandervaere, J., Zin, I., Braud, I., Heistermann, M., Legoût, C., Molinié, G., Nord, G., 2018. How does initial soil moisture influence the hydrological response? A case study from southern France. Hydrology and Earth System Sciences Discussions, 1-43. https://doi.org/10.5194/hess2018-28

van Genuchten, M.Th., 1980. A closed-form equation for predicting the hydraulic conductivity of unsaturated soil. Soil Science Society of America Journal, 44, 5. https://doi.org/10.2136/sssaj1980.03615995004400050002x

van Genuchten, M., Leij, F., Yates, S., Williams, J., 1991. The RETC Code for quantifying hydraulic functions of unsaturated soils. EPA/600/2-91/065, R.S. 83.

Villarreal, E., Davies, A., Bengtsson, L., 2004. Inner city stormwater control using a combination of Best Management Practices. Ecological Engineering, 22, 279-298. https://doi.org/10.1016/j.ecoleng.2004.06.007

Vogel, T., Cislerova, M., Hopmans, J., 1991. Porous media with linearly variable hydraulic properties. Water Resources Research, 27, 2735-2740. https://doi.org/10.1029/91WR01676

Willaredt, M., Nehls, T., 2021. Investigation of water retention functions of artificial soil-like substrates for a range of mix- ing ratios of two components. Journal of Soils and Sediments, 21, 2118-2129. https://doi.org/10.1007/s11368-02002727-8

Wong, T., Fletcher, T., Duncan, H., Jenkins, G., 2006. Modelling urban stormwater treatment - A unified aproach. Ecological Engineering, 27, 58-70. DOI: 10.1016/j.ecoleng.2005.10.014

Zhang, K., Chui, T.F.M., 2017. Evaluating hydrologic performance of bioretention cells in shallow groundwater. Hydrological Processes, 31, 4122-4135. https://doi.org/10. 1002/hyp.11308

Zhu, Y., Irmak, S., Jhala, A.J., Vuran, M.C., Diotto, A., 2019. Time-domain and frequency-domain reflectometry type soil moisture sensor performance and soil temperature effects in fine- and coarse-textured soils. Applied Engineering in Agriculture, 35, 117-134. DOI: 10.13031/aea.12908

\section{NOMENCLATURE}

LID Low Impact Development

WSUD Water Sensitive Urban Design

$\mathrm{SuSD} \quad$ Sustainable Drainage Systems

$B P M \quad$ Best practice management

$N B S \quad$ Nature Best Solution

$B C \quad$ Bioretention cell

LOI Loss-On-Ignition Method

$K_{S} \quad$ saturated hydraulic conductivity

UCEEB University Centre for Energy Efficient Buildings

$C T U$ Czech Technical University in Prague

TDR Time domain reflectometry

$K_{a} \quad$ apparent dielectric constant

$E C \quad$ electric conductivity

$\theta_{v} \quad$ actual volumetric water content

$\theta_{r} \quad$ residual water content

$\theta_{r} \quad$ saturated water content

$\alpha \quad$ shape parameters of retention curve

$n \quad$ shape parameters of retention curve

$P E \quad$ ponding experiment

$K_{\text {seff }} \quad$ effective saturated hydraulic conductivity

$K_{\text {slab }} \quad$ initial saturated hydraulic conductivity measured in

laboratory

$L_{b} \quad$ biofilter thickness

$L_{s} \quad$ sand layer thickness

$K_{s b} \quad$ saturated hydraulic conductivity of biofilter

$K_{s s} \quad$ saturated hydraulic conductivity of sand

$q_{m} \quad$ flux density

$L \quad$ length of the whole medium

$\Delta H \quad$ difference of hydraulic head at the top and bottom of

$\Delta H \quad$ the two layer column

$Q \quad$ measured outflow from $\mathrm{BC}$

A cross-sectional area or flow rate area

$K_{s b f} \quad$ fitted saturated hydraulic conductivity of biofilter in

$K_{s b f} \quad$ Hydrus

$q_{f} \quad$ fitted density flux

$Q_{s f} \quad$ seepage face flux 


\section{SUPPLEMENTARY MATERIALS}

a)

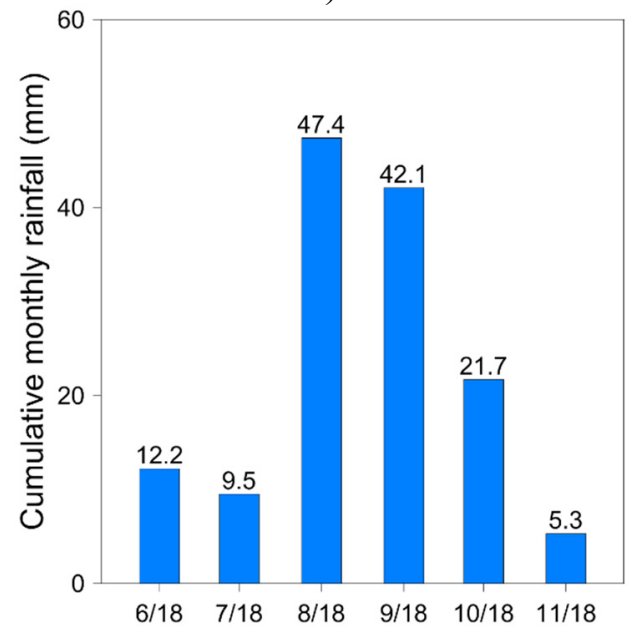

b)

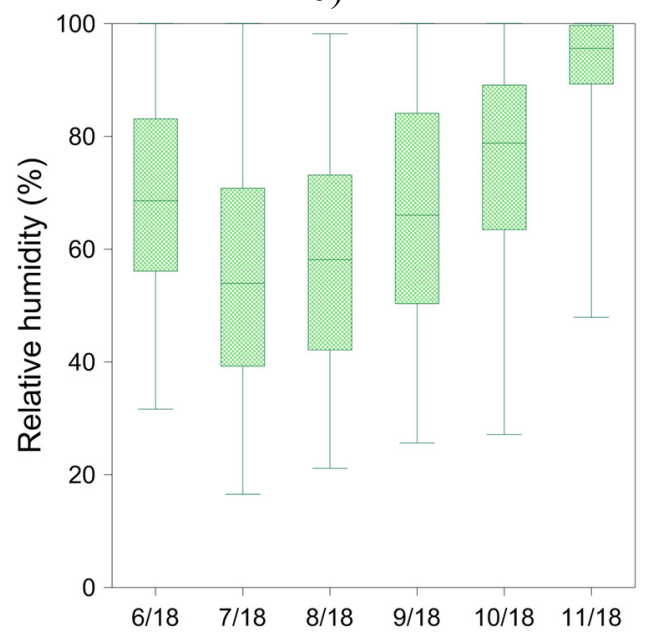

Fig. S1. a) Cumulative monthly rainfall; b) Monthly relative humidity in evaluation period measured on experimental site by meteorological station North-East from 18.6. 2018 to 22.11.2018. June and November do not represent whole months.

a)

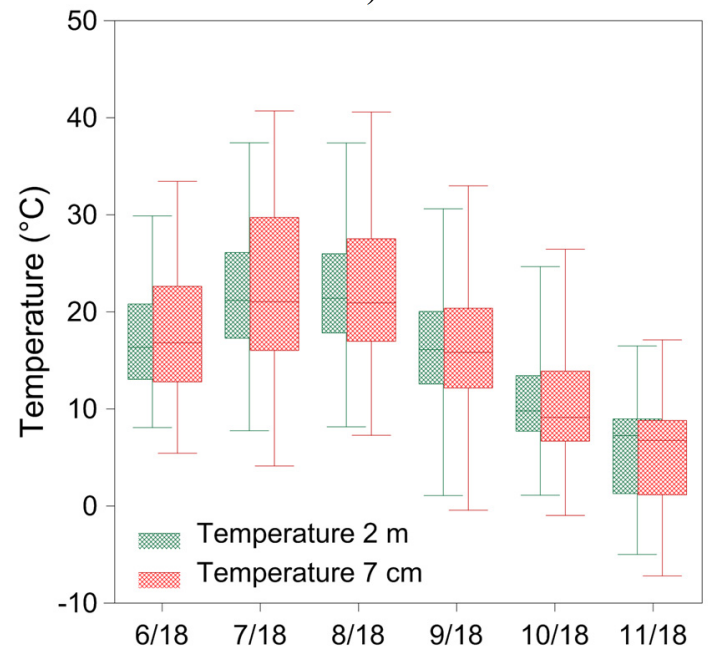

b)

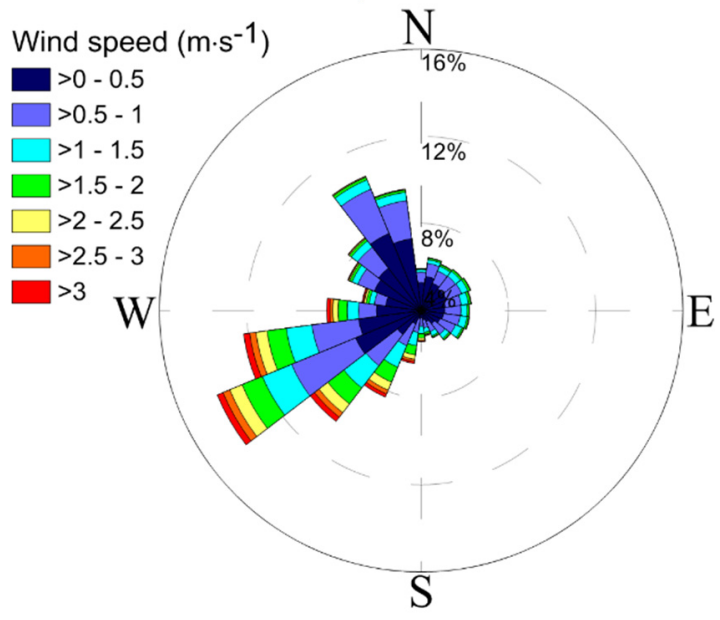

Fig. S2. a) Monthly temperature measured in high $7 \mathrm{~cm}$ and $2 \mathrm{~m}$ above the surface. The boxplot displaying the minimum, the maximum, the sample median, and the first and third quartiles. b) Wind rose in evaluation period measured at the experimental site by meteorological station in the period from 18.6.2018 to 22.11.2018.

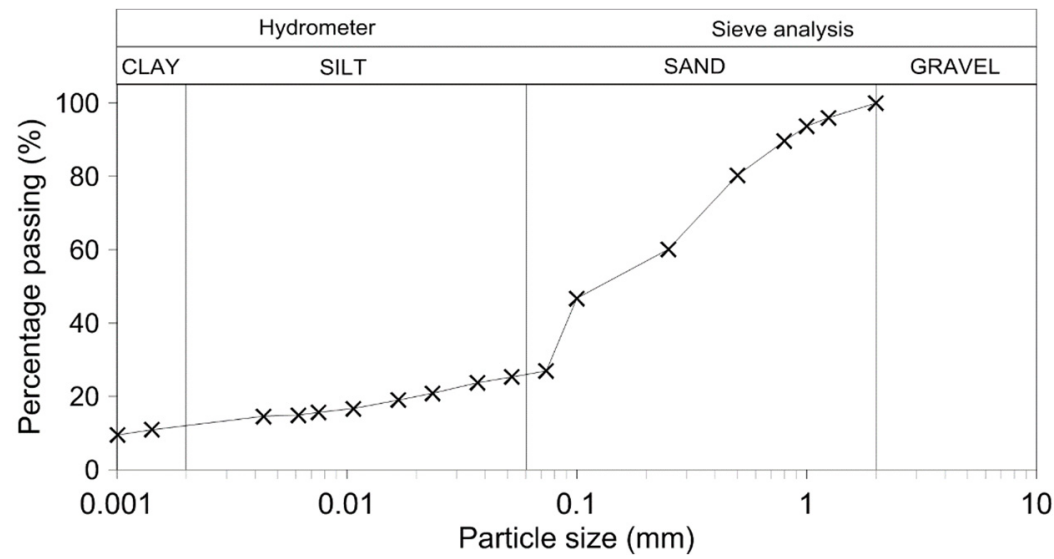

Fig. S3. Particle size distribution of biofilter used, where clay particles are smaller than $0.002 \mathrm{~mm}$ in diameter, silt particles are from 0.002 to $0.05 \mathrm{~mm}$, sand ranges from 0.05 to $2.0 \mathrm{~mm}$, and gravel particles are larger than $2 \mathrm{~mm}$. 


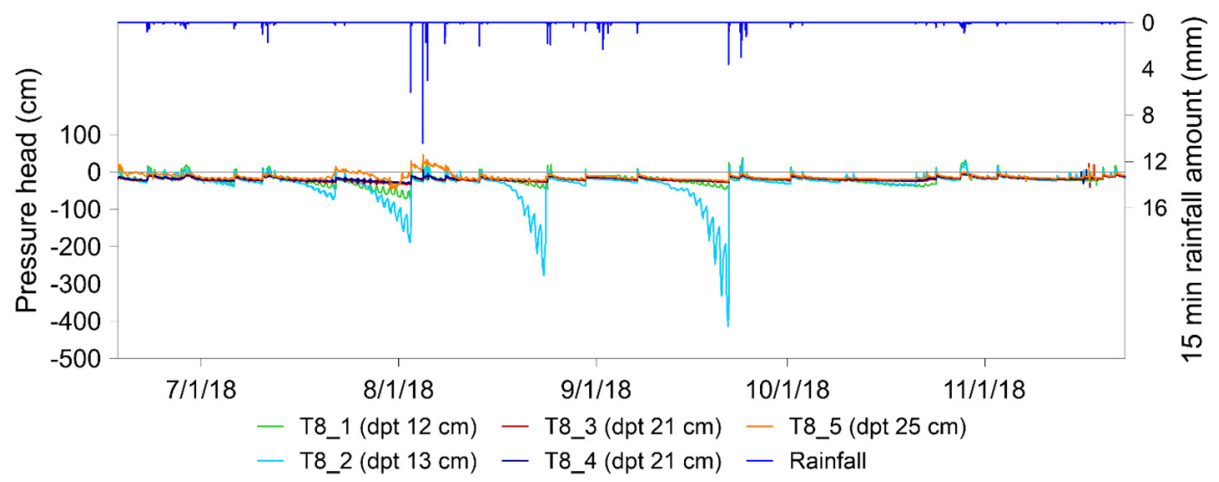

Fig. S4. Pressure head conditions in the biofilter in $\mathrm{BC} 1$ as recorded by tensiometers.

a) 5.6 .2018

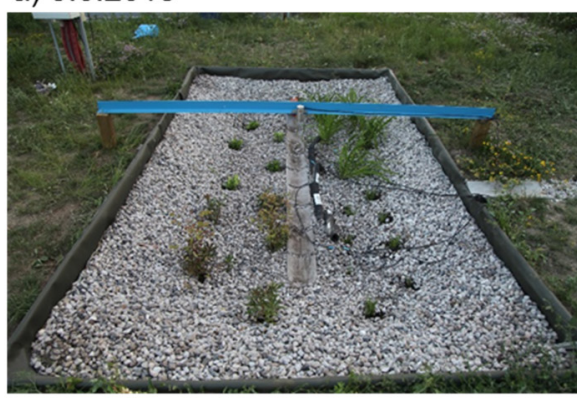

c) 10.8 .2018

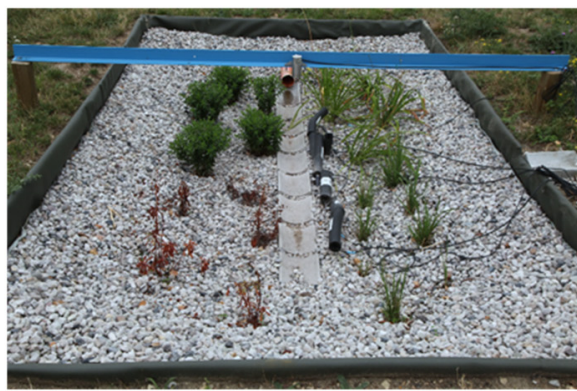

b) 19.7 .2018

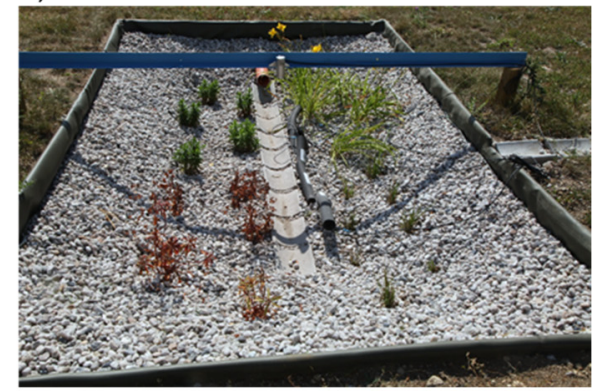

d) 11.9 .2018

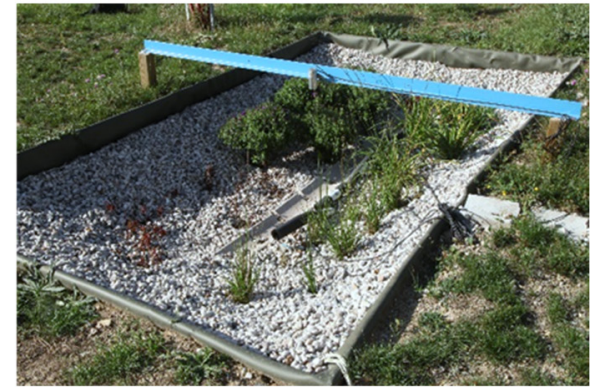

Fig. S5. Vegetation growth during the evaluation period 18/6/2018 to 22/11/2018 is shown in four selected photographs (a-d).

a)

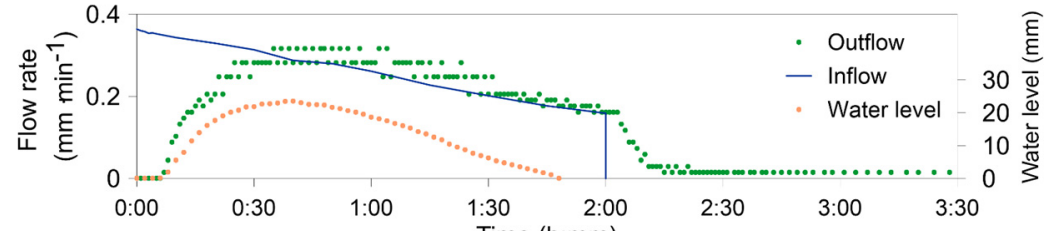

b)

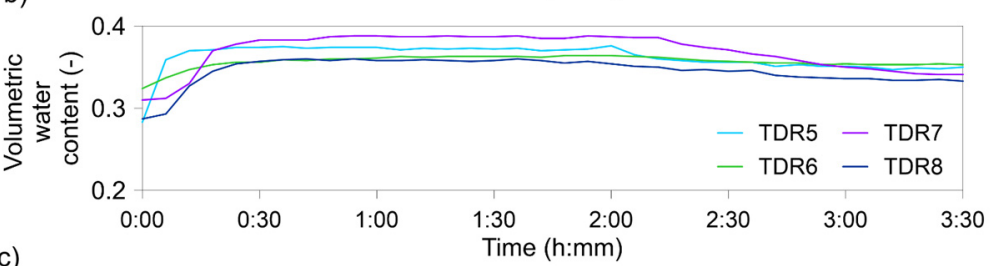

c)

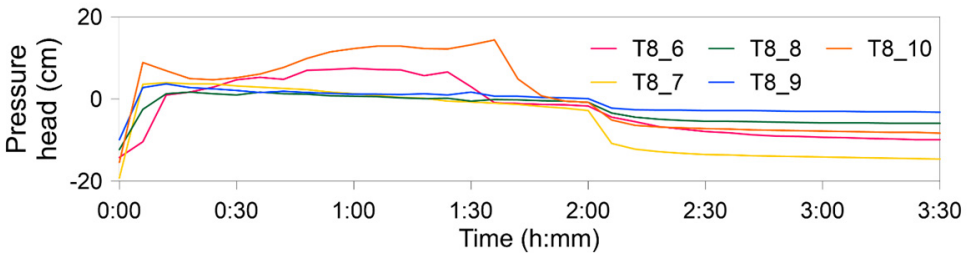

Fig. S6. Detailed view of recorded: a) fluxes and water level; b) volumetric water contents of the biofilter; c) pressure heads in a ponding experiment conducted on $\mathrm{BC} 2$. Volumetric water content and pressure head show initial and actual conditions of biofilter. The tensiometers are placed in depths: T8_6 $(17 \mathrm{~cm})$, T8_7 $(13 \mathrm{~cm})$, T8_8 $(20 \mathrm{~cm})$, T8_9 $(25 \mathrm{~cm})$, T8_10 $(19 \mathrm{~cm})$. 


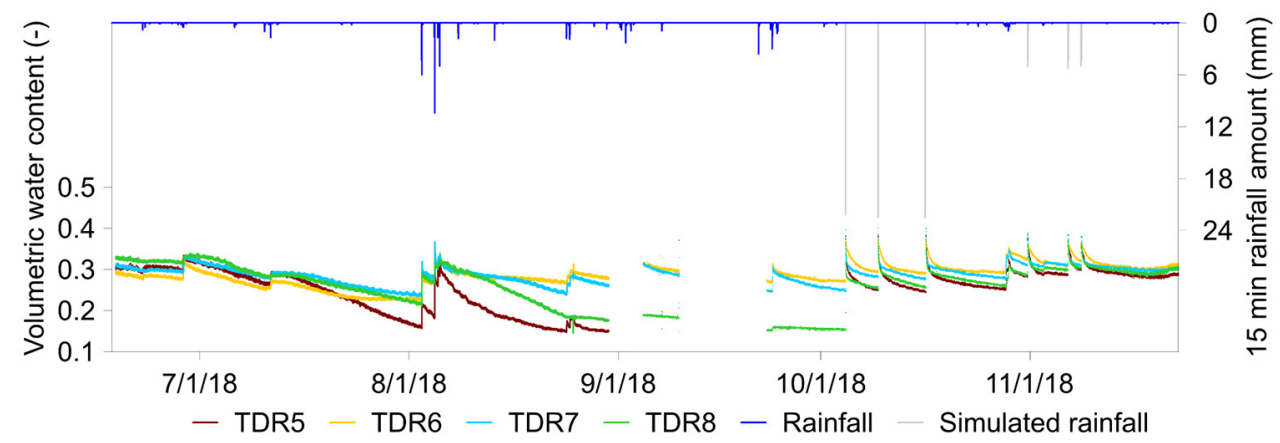

Fig. S7. Volumetric water content conditions of biofilter layer of $\mathrm{BC} 2$ during the monitoring period. Grey lines represent simulated rainfall, the size of which is related to the area of the roof drained by $\mathrm{BC} 1$ of $38 \mathrm{~m}^{2}$.

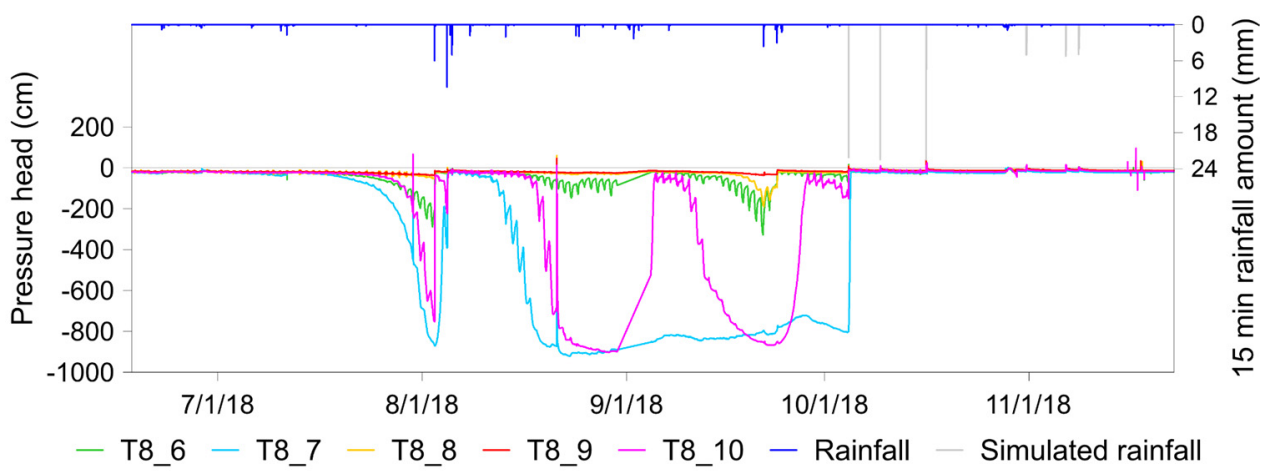

Fig. S8. Pressure head conditions of biofilter from 18/6/2018 to 22/11/2018 in BC2. The grey lines represent simulated rainfall, the size of which is related to the area of the roof drained by $\mathrm{BC} 1 \mathrm{of} 38 \mathrm{~m}^{2}$. Depth of tensiometers: $17 \mathrm{~cm}$ (T8_6), $13 \mathrm{~cm}$ (T8 8 ), $20 \mathrm{~cm}$ (T8 8), $25 \mathrm{~cm}$ (T8_9), 19 cm (T8_10).

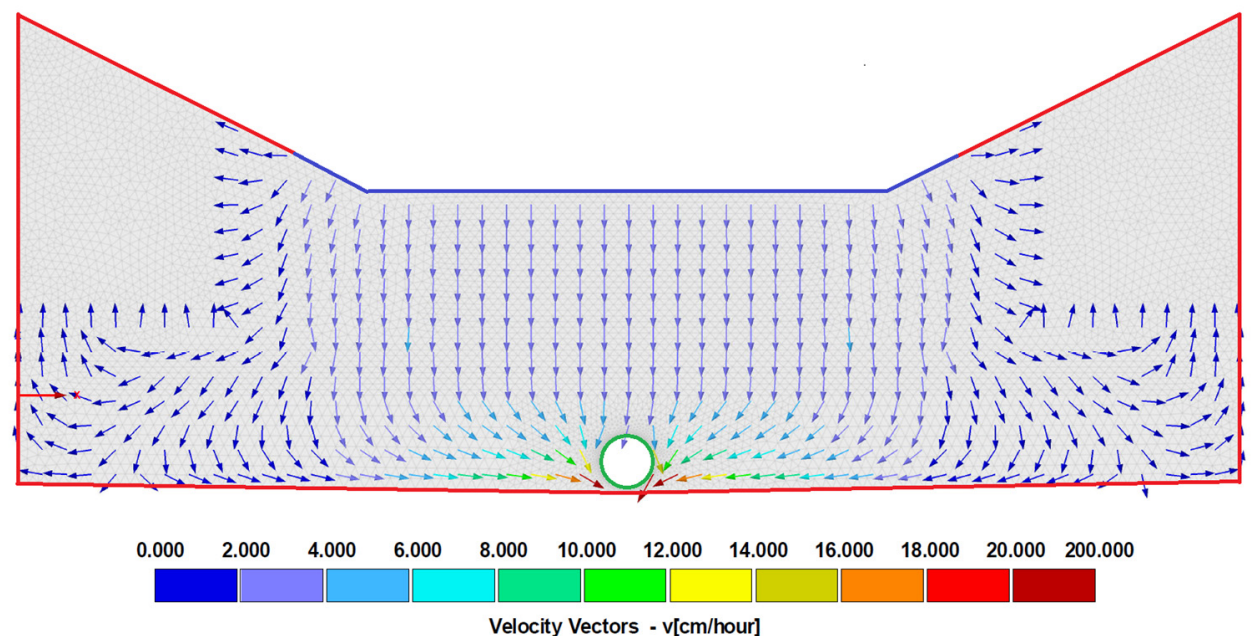

Fig. S9. Result of the flow direction and velocity of the flow in Hydrus 2D mode at time 2 hour after beginning of infiltration, when steady state was reached. The schema shows the boundary conditions (red line - No flux, green line - Seepage face, blue line - Constant pressure head) and the height of the constant water level. 


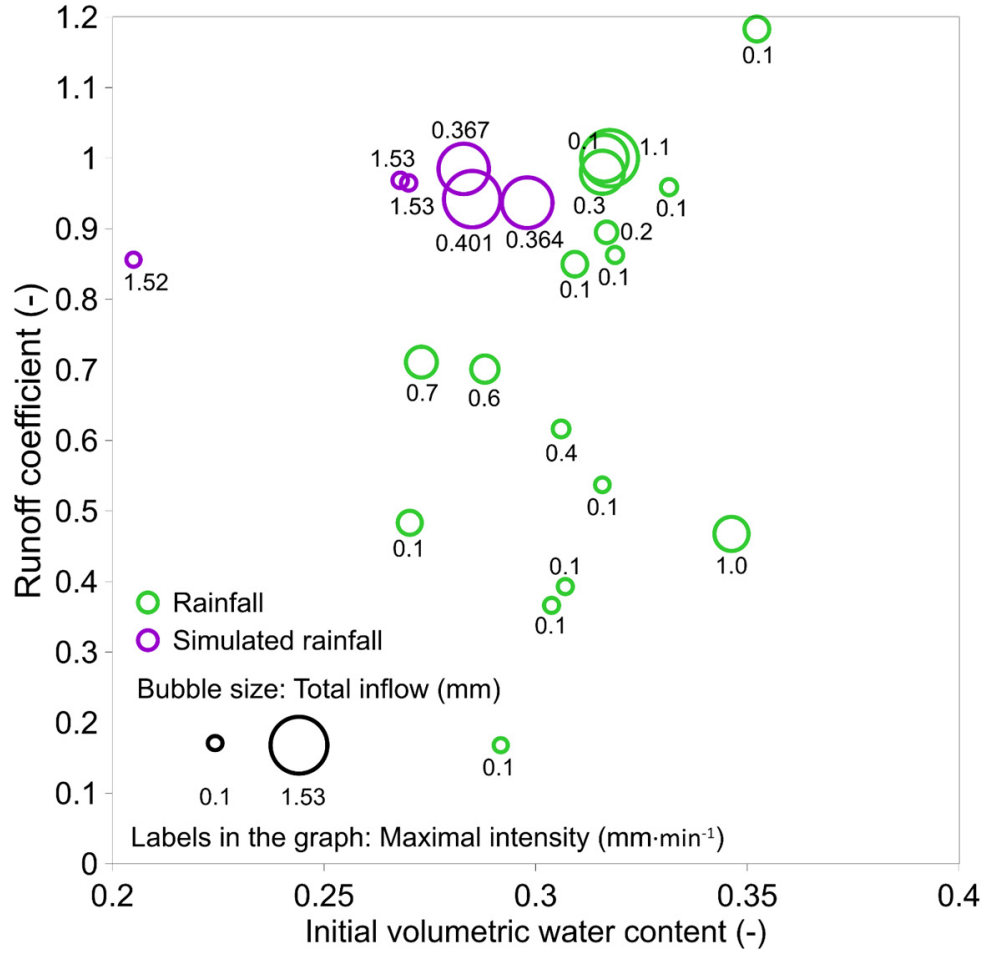

Fig. S10. Detailed display of rainfall-runoff episodes depending on the initial volumetric water content in the both bioretention cells from $18 / 6 / 2018$ to $22 / 11 / 2018$. Green bubbles show rainfall in the BC1 (17 episodes) and the purple bubbles show simulated rainfall episodes in the BC2 (6 episodes). The value of volumetric water content is average from four TDR. In general, the episodes with lower initial volumetric water content, expressed as the average of four TDR sensors readings, and, at the same time, lower maximal intensity and rainfall depth clearly resulted in a lower runoff coefficient. 